\title{
Cronología histórica sobre los archivos españoles*
}

\author{
Historic chronology about the spanish archives
}

\author{
Pedro Luis Lorenzo Cadarso**
}

\begin{abstract}
RESUMEN
ABSTRACT

El artículo contiene un repertorio de noticias sobre la historia de los archivos y de la archivística en España desde el siglo

XIII hasta época actual. Las noticias seleccionadas son leyes y normativas dictadas por las autoridades públicas, publicación de monografías relacionadas con la archivística y noticias sobre la

This article contains a repertory of news about the history of the archives in Spain from the XIII century to present times. The selected news are laws and rules enacted by public authorities, monographs related on archives and news about the foundation and organization of the archives.
\end{abstract} fundación y organización de los archivos.

\author{
PALABRAS CLAVE \\ archivística, historia de España, \\ cronología
}

\section{KEY WORDS}

Archive editions, Spanish history, chronology

\section{EL MARCO HISTÓRICO}

Sabemos de la existencia de archivos en la Península lbérica al menos desde la dominación romana y que, aunque la cultura escrita retrocediese de forma muy notable después, también los poseían la Iglesia y la Corona durante la dominación visigoda y en los siglos posteriores. Sin embargo, las noticias concretas que po-

* Fecha de recepción del artículo: 2008-11-09. Fecha de admisión del artículo: 2009-01-09.

** Profesor Titular de Universidad de Ciencias y Técnicas Historiográficas. Departamento de Historia, Facultad de Biblioteconomía y Documentación, Universidad de Extremadura (Plazuela Ibn Marwan, 06071-Badajoz). C.e.: plorenzo@unex.es. 
seemos sobre el panorama archivístico hasta el siglo XIII son tan escasas y dispersas que no tiene utilidad, a mi juicio, recogerlas en una cronología planteada al modo en que yo lo he hecho.

Por el contrario, durante el siglo XIII se produjeron una serie de cambios institucionales, jurídicos y socioculturales que hicieron que el problema de la custodia y conservación de los documentos comenzase a ser un asunto si no prioritario, sí al menos con la suficiente importancia como para que se empezase a hablar de archivos con cierta frecuencia. Efectivamente, en el siglo XIII los reyes comienzan a articular una estructura administrativa crecientemente burocratizada y a ello contribuye también la extensión del derecho romano-canónico (con las Partidas de Alfonso $\mathrm{X}$, por ejemplo ${ }^{1}$ ), por lo que se dictan normas sobre expedición y control de documentos cada vez más detalladas (es en esta época cuando aparecen los registros de Cancillería), que implicaban también la custodia de los mismos en incipientes archivos. Paralelamente, entre la sociedad civil, la extensión del notariado hizo que la producción de documentos aumentase exponencialmente y conservarlos era también un fenómeno nuevo que habrá de regularse ${ }^{2}$. De todos modos, durante el siglo XIII las noticias sobre archivos rara vez superan el ámbito eclesiástico y cuando lo hacen nos encontramos con simples cartularios o registros donde se copian cartas reales o privilegios, custodiados normalmente, incluso cuando se trataba de la Cancillería Real, en iglesias y monasterios.

A pesar de ello, hemos considerado que el siglo XIII era el punto de partida más lógico —o al menos el más práctico- para nuestro trabajo, aunque advirtiendo que hasta el siglo siguiente no tenemos noticias, si excluimos al notariado, de verdaderos archivos civiles (el primer archivo real, por ejemplo, se funda en la Corona de Aragón en 1318). A partir del siglo XIV, las noticias sobre archivos aumentan hasta hacerse relativamente frecuentes, pues los concejos, los aristócratas o el rey producen o reciben documentos con cierta asiduidad y el notariado se extiende por casi todos lados, supliendo el persistente problema de un analfabetismo generalizado. Es en estos siglos también cuando nos encontramos por primera vez con leyes dirigidas a garantizar la conservación de determinados documentos por los funcionarios que los expiden (1247 en Valencia, 1256 en Castilla), que estarán en el origen de los primeros archivos no eclesiásticos ${ }^{3}$.

\footnotetext{
1 Véase para la Castilla de Alfonso X: LÓPEZ GUTIÉRREZ, A. J., «Registros y registradores en la cancillería de Alfonso X», en Estudis Castellonencs, 6, 1994-1995, págs. 709-720; y para Aragón en la época de Jaime I: ARAGÓ, A. M. y TRENCHS ODENA, J., «Los registros dela Corona de Aragón (Jaime I y Pedro II) y los registros pontificios", en Anali de la Scuola Speciale per Archivisti e Bibliotecari dell'Università di Roma, XII, 1972, págs. 26-39.

2 Véase CANELLAS LÓPEZ, A., «La investigación diplomática sobre cancillerías y oficinas notariales. Estado actual y posibles investigaciones», en I Jornadas de Metodología Aplicada a las Ciencias Históricas. V: Paleografía y Diplomática, Santiago de Compostela, 1975, págs. 201-222; VV.AA., Congreso Internacional de Diplomática: Notariado público y documento privado: de los orígenes al siglo XIV, Valencia, 1989, 2 vols.

3 Sobre la Cancillería Real Catalanoaragonesa en los siglos XIII-XV, véase: ARAGÓ, A. M. y TRENCHS, J., «Las cancillerías de la Corona de Aragón y Mallorca desde Jaime I hasta la muerte de Juan II», en Folia Parisensia, 1, Zaragoza, 1983.
} 
Desde el siglo XV y hasta finales de la Edad Moderna, los archivos son ya un fenómeno generalizado, incluso a nivel privado, pero son sólo una herramienta jurídico-administrativa, una salvaguarda de derechos: se conservan los documentos antiguos que se suponía que podrían ser de alguna utilidad en el futuro, esto es, los constitutivos de derecho, de ahí que los demás, los que llamaríamos de trámite, se destruyesen de forma sistemática hasta bien entrada la Edad Moderna. Además, múltiples prácticas medievales, por llamarlas de algún modo, perduraron durante mucho más tiempo del que podría sospecharse, como la oralidad en la resolución de los asuntos (todavía en 1500, los Capítulos de corregidores recordaban a estos jueces que los sumarios debían instruirse por escrito) o la custodia de los documentos en sus casas por los oficiales que los tramitaban (todavía en 1607, Felipe III recordaba a los escribanos de cámara de la Chancillería de Valladolid que no podían quedarse con los sumarios sentenciados, sino que debían depositarlos en el archivo del tribunal) $)^{4}$.

En cualquier caso, a partir del siglo XV se podrían recoger centenares de noticias sobre archivos de todo tipo, pues ya eran, como hemos dicho, un fenómeno bastante generalizado e incluso en determinados ámbitos públicos, obligatorios por ley. Por este motivo, en esta época hemos procurado ser más selectivos en las noticias que recogemos y limitarnos a aquellas con una repercusión que iba más allá de lo local o particular.

Un nuevo ciclo en la historia de los archivos comienza a vislumbrarse en España desde mediados del siglo XVIII, y especialmente tras el ciclo de las guerras napoleónicas, cuando el interés por los archivos irá más allá de su utilidad jurídicoadministrativa y a los papeles viejos se les dará un valor patrimonial (por primera vez en España, en términos jurídicos, en 1779) y científico, como fuente para una nueva historia que habría de ser verificable y hacerse con documentos de archivo (las órdenes de Carlos III en 1778 para escribir una nueva historia de la coIonización española, el trabajo de la Escuela Benedictina de Valladolid ${ }^{5}$ o los «viajes literarios", financiados por Ensenada treinta años antes, están entre los primeros síntomas de este cambio de concepción en España).

Los orígenes de esta nueva actitud hacia los documentos históricos y por extensión hacia los archivos se habían fraguado, en términos intelectuales, mucho antes, en el marco primero de los debates eclesiásticos en torno a la autenticidad de los documentos con los que se pretendía elaborar una hagiografía verificable. Es en este ambiente religioso en el que se inscriben los trabajos pioneros de Flacius Siliricus (1560-1574) o del Cardenal Baronio (1593-1607); y ya a mediados del siglo XVII, las conocidas como bella diplomatica, en las que se inscribe el trabajo de Daniel Von Papenbroch, Jean Bolland y, sobre todo, Mabillón, que en 1681 pu-

\footnotetext{
${ }^{4}$ Véase para organización de estos primeros archivos RODRÍGUEZ DE DIEGO, J.L., Instrucción para el gobierno del archivo de Simancas, Madrid, 1989.

${ }_{5}^{5}$ Véase FERNÁNDEZ FLOREZ, J. A., "La Congregación Benedictina de Valladolid en el siglo XVIII», en Erudición y discurso histórico: Las instituciones europeas, Valencia, 1993, págs. 101-128.
} 
blicaba De re diplomatica libri sex o Seis libros sobre la Diplomática, que suponía el nacimiento formal de esta disciplina y con ella el de una nueva forma de enfocar el trabajo del historiador, que para garantizar su veracidad, habría de hacerse a partir de entonces con documentos de archivo previamente estudiados y valorados.

A los políticos de la segunda mitad del siglo XVIII, en cualquier caso, les importaba bien poco la heurística, y si financiaron el trabajo de determinados historiadores o diplomatistas o si se preocuparon incluso de fundar archivos históricos, fue por motivos mucho más pragmáticos: si Ensenada financió al Padre Flórez, entre otros, fue porque esperaba con ello lograr argumentos jurídicos para las negociaciones con el Papado del Concordato $;$ y si Carlos III y Carlos IV hicieron lo mismo con el Archivo de Indias fue para tratar de contrarrestar de algún modo la pésima imagen exterior que la Leyenda Negra había creado de España, país que era retratado en el siglo XVIII como el paradigma del oscurantismo y la brutalidad. De todos modos, aunque primasen motivaciones políticas circunstanciales, el ambiente hacia los documentos antiguos y los archivos cambió con toda evidencia a lo largo de las últimas décadas del siglo $\mathrm{XVIII}$, al menos entre las élites instruidas, y ello preparó el camino para las políticas archivísticas mucho más decididas que se intentarían en el siglo siguiente.

Pasado el marasmo que se abrió con la Revolución francesa y las subsiguientes guerras napoleónicas, desde las primeras décadas del siglo XIX existe una voluntad política clara de crear un sistema archivístico que garantizase la conservación de nuestro patrimonio documental, que no se lograse del todo hay que achacarlo más a la falta de recursos que a la ausencia de interés político. En este siglo, la legislación sobre archivos es ya extremadamente numerosa e incluso se llega a alcanzar cierto grado de profesionalización en su gestión, sobre todo tras la aparición del Cuerpo Facultativo de Archiveros (1858) y de las entidades administrativas que controlaban los archivos públicos (1847). El problema, obviamente, fue que las buenas intenciones nunca tuvieron el acompañamiento presupuestario que necesitaban y, para complicar todavía más las cosas, la inestabilidad política del siglo afectó también a la falta de continuidad o incluso de aplicación práctica de determinados aciertos legislativos ${ }^{8}$. Con todo, el modelo archivístico que se diseñó a mediados del siglo XIX se mantendrá en sus líneas maestras hasta época actual, cuando la descentralización del Estado ha afectado profundamente a la configuración de nuestra red de archivos.

Paralelamente, la legislación sobre protección del Patrimonio Histórico, aunque extremadamente escasa y liviana hasta la II. ${ }^{a}$ República (en 1900 se dicta la primera ley integral de protección del Patrimonio), comienza a proteger también a los

6 Véase GÓMEZ URDÁÑEZ, J. L., El proyecto reformista de Ensenada, Lérida, 1999.

7 Véase GÓMEZ GÓMEZ, M., «Crítica histórica y archivos. El caso de España en el siglo XVIII», en Historia. Instituciones. Documentos, 12, 1986, págs. 199-231.

8 Véanse los trabajos contenidos en GENERELO, J. J. y MORENO LÓPEZ, A., Historia de los archivos y de la archivística en España, Valladolid, 1998. 
documentos históricos de los archivos (en 1873, por ejemplo, fueron procesados los responsables municipales de Burguillos por vender la documentación de su archivo municipal).

\section{CRITERIOS TÉCNICOS DE ELABORACIÓN}

Las noticias las he redactado del modo más sucinto y claro que me ha sido posible, pues no pretenden explicar en profundidad los asuntos, sino sólo señalar su existencia y permitir así una consulta más ágil del texto. Las noticias que contiene pueden clasificarse del siguiente modo:

- Disposiciones gubernamentales (incluidas algunas de la Iglesia) acerca de la fundación y organización de los archivos.

- Disposiciones gubernamentales relacionadas directa o indirectamente con los archivos (personal, patrimonio histórico, regulaciones del procedimiento administrativo o judicial, regulaciones del notariado y de las principales entidades productoras de documentos etc.).

- Publicación de los primeros tratados de archivística o disciplinas afines en España y libros históricos sobre las prácticas administrativas y judiciales en España.

- Acontecimientos de especial relevancia en la organización interna de los principales archivos del país.

- Noticias relacionadas con los archivos indirectamente, pero significativas, como la legislación fundamental sobre Patrimonio Histórico, normas sobre la edición de impresos o las novedades en formas de escritura y tipologías documentales.

Siempre que me ha sido posible, he indicado la categoría jurídica o diplomática de las disposiciones, sin embargo, en determinadas recopilaciones legislativas esta información no aparece (algo que sucede muy a menudo, por ejemplo, en las Ordenanzas reales de Castilla de Díaz de Montalvo) o lo hace con multitud de errores, confundiendo las categorías diplomáticas de los documentos dispositivos reales (algo que ocurre con mucha frecuencia en las recopilaciones de los siglos XVI al XVIII, incluida la Novísima Recopilación). Durante el siglo XIX, la principal fuente disponible, la Gaceta de Madrid, presenta también muchas dificultades, pues confunde a menudo la presentación de proyectos de ley con la promulgación en sí de la disposición (lo cual, a veces, ni siquiera llegaba a suceder luego en la práctica) o sólo incluye resúmenes periodísticos de las disposiciones. Para épocas más recientes ya no hay tantas dificultades con las fuentes, si acaso un reglamentismo tan extremado que el número de noticias supera cualquier previsión y se hace necesario renunciar a dar noticia de todas ellas. 
En cuanto a las fuentes empleadas, éstas han sido, lógicamente, muy diversas, pero cabe destacar, para época contemporánea, el Boletín Oficial del Estado, que sigue teniendo interés en épocas anteriores (la Gaceta de Madrid se editó desde 1661, pero no es tan fiable como otras fuentes). Las diversas recopilaciones de leyes también han aportado múltiples noticias, especialmente las ya citadas Ordenanzas Reales de Castilla $(1484)^{9}$ y la Novísima recopilación $(1804)^{10}$, junto con diversas recopilaciones de Autos Acordados y otras disposiciones de los Consejos y Secretarías que se hicieron a partir del siglo XVII ${ }^{11}$, casi todas ellas disponibles en la base de datos con documentos digitalizados $\mathrm{Le}$ gislación Histórica Española, de la Real Academia de la Historia o en recopilaciones impresas ${ }^{12}$. En menor medida, aunque también tienen algún interés, se han utilizado algunos repertorios o prontuarios de leyes, esto es, índices que se prepararon en la época para facilitar las consultas legislativas a los profesionales del derecho ${ }^{13}$.

Los Acuerdos de Cortes son fácilmente accesibles a través de las ediciones que hizo la Real Academia de la Historia, tanto de las castellanas como de las aragonesas ${ }^{14}$. También ha sido de gran interés la consulta de la Revista de Archivos, Bibliotecas y Museos - sobre la que se elaboró un excelente índice en 1959-, editada desde 1871 y que contiene un enorme número de noticias sobre la vida profesional de los archiveros. El Boletín de ANABAD también tiene interés, aunque en su primera etapa, hasta los años ochenta, era una publicación muy humilde y con pocos contenidos. Siempre que me ha sido posible, pues suelen contener noticias mucho más contrastadas, se han consultado las guías de los archivos, al me-

9 DÍAZ DE MONTALVO, A., Compilación de leyes del Reino [Ordenanzas Reales de Castilla o Libro de las Leyes], Huete, 1484. Ed. facsímil en Valladolid, Lex Nova, 1986. Está disponible su edición digitalizada en el catálogo de la B.N.

10 Novísima recopilación de las leyes de España, Madrid, 1804. Ed. facsímil en Madrid, B.O.E., 1975, 6 vols.

11 Durante los siglos XVI, XVII y XVIII se editaron varias decenas de recopilaciones de leyes por materias, cronológicas o referidas a determinados territorios, de todas ellas pueden destacarse: ARAZTIA, P. de, Autos acordados antiguos y modernos del Consejo, Madrid, 1723; IBARRA, J., Autos acordados por el orden de Título de las Leyes de la Recopilación, Madrid, 1777; SÁNCHEZ, S., Colección de pragmáticas, cédulas, provisiones y autos acordados y otras providencias generales expedidas por el Consejo Real en el reinado del señor Carlos IV, Madrid, 1805; BRO, J., Colección de pragmáticas y reales cédulas de Su Majestad y autos acordados por los señores del Consejo, Gerona, 1789; PIMENTEL, J. A., Leyes de Recopilación y autos acordados, Madrid, 1745; Novísima recopilación de las leyes del reino de Navarra desde el año 1512 hasta el de 1716, Pamplona, 1735, 2 vols.; CARRERA, Diego de la, Autos y acuerdos del Consejo desde 1532 hasta 1648, Madrid, 1649; Recopilaciones de las Reales Cédulas, Decretos y Pragmáticas expedidas desde 1680 a 1735, Sevilla, 1735.

12 Fundamentalmente en la obra Códigos españoles concordados y anotados, Madrid, 1847, 12 vols.

13 Por ejemplo, CELSO, H. de, Repertorio universal de todas las leyes destos reinos de Castilla, Medina del Campo, 1553 ed. Madrid, B.O.E., 2000; y AGUIRRE, S., Prontuario alfabético y cronológico por orden de materias de las instrucciones, ordenanzas, reglamentos, pragmáticas y demás reales resoluciones no recopiladas que han de observarse para la administración de justicia y gobierno en los pueblos del Reino, Madrid, Imprenta Real, 1799.

14 REAL ACADEMIA DE LA HISTORIA, Cortes de los antiguos reinos de Castilla y León, Madrid, 1861-1903; y id., Cortes de los antiguos reinos de Aragón, Valencia y Principado de Cataluña, Barcelona, 1896-1918, 25 vols. 
nos las de los principales, así como determinadas monografías sobre algunos archivos concretos y sobre historia de la archivística ${ }^{15}$.

En conclusión, las fuentes disponibles - $\mathrm{O}$ al menos las más accesiblesson bastante exhaustivas para conocer el marco legislativo o, a nivel más general, la política archivística de las instituciones públicas centrales, pero no lo son tanto para reconstruir lo que convencionalmente llamamos historia de la custodia de los distintos fondos documentales, que exigirían de una investigación detallada para cada uno de ellos. De todos modos, cuando ha sido posible, se ha intentado incluir algunas noticias sobre este asunto, al menos para las secciones más valiosas de los grandes archivos centrales, puesto que disponen de algunas publicaciones detalladas sobre este particular ${ }^{16}$.

\section{PERIODIZACIÓN GENERAL}

El gran número de fechas y acontecimientos que se reseñan en la cronología podría llegar a generar cierta confusión, por eso creo que conviene empezar por establecer las fases que encontramos en el periodo cronológico que estudiamos, así como los hechos fundamentales que se producen en cada una de ellas ${ }^{17}$ :

15 De especial interés nos han sido las siguientes publicaciones: Álvarez Pinedo, F. J. y Rodríguez de Diego, J. L., Los archivos españoles: Simancas, Madrid, 1993; ASOCIACIÓN ESPAÑOLA DE ARCHIVEROS ECLESIÁSTICOS, Guía de los Archivos y Bibliotecas de la Iglesia Española, León, 1985; Carmona de los Santos, M., Guía del Archivo Central del Ministerio de Educación y Ciencia, Alcalá de Henares, 1975; Cortés Alonso, V., Archivos en España y América. Materiales para un manual, Madrid, 1979; Crespo Nogueira, C., Archivo Histórico Nacional. Guía, Madrid, 1989; Escudero de la Peña, J.M.a, «El Archivo General de Valencia», en Revista de Archivos, Bibliotecas y Museos, 1973; Fernández Catón, J.M., Los archivos de la Iglesia en España, León, 1976; Fuster Ruiz, F., «Los inicios de la archivística española y europea", en Revista General de Información y documentación, Vol. 6-1, 1996, págs. 43-77; Generelo, J.J. y Moreno, A. (coords.), Historia de los archivos y de la archivística en España, Valladolid, 1998; Gil Merino, A., Archivo Histórico del Reino de Galicia, Madrid, 1976; Lacarra, J.M. a , Guía del Archivo General de Navarra, Madrid, 1954; López Gómez, P. y Gallego, O., Clasificación de los fondos de Archivos Históricos Provinciales, Madrid, 1980; Martín Postigo, M. a S., Historia del Archivo de la Real Chancillería de Valladolid, Valladolid, 1979; Martínez Ferrando, E., Archivo de la Corona de Aragón. Guía abreviada, Madrid, 1958; Mendo Carmona, C., «El largo camino de la Archivística: de práctica a ciencia», en Signo, 2 , 1995, págs. 113-132; Ministerio de Defensa, Guía de los archivos militares españoles, Madrid, 1995; Monterero y Simón, C., «Archivo del Real Palacio de Madrid», en Hidalguía, 28, 1958, págs. 481-496; Mut Calafell, A., El Archivo del Reino de Mallorca, Palma de Mallorca, 1983; Núñez Alonso, P., Archivo de la Real Chancillería de Granada, Guía del investigador, Madrid, 1984; PEIRÓ MARTíN, I. y PASAMAR ALZURÍA, G., La Escuela Superior de diplomática. Los archiveros en la historiografía española contemporánea, Madrid, 1996; Peña y Cámara, J. de la, Archivo General de Indias de Sevilla. Guía del visitante, Madrid, 1958; Plaza Bores, A. de la, Archivo General de Simancas. Guía del investigador, Madrid, 1983; Udina Martorell, F., Guía histórica y descriptiva del Archivo de la Corona de Aragón, Madrid, 1986; y López Rodríguez, C. ¿Qué es el archivo de la Corona de Aragón?, ed. Mira, Zaragoza, 2007.

${ }_{16}$ Bien estudiada está, por ejemplo, la azarosa custodia de los fondos que hoy forman la Sección de Consejos del Histórico Nacional en ÁLVAREZ-COCA, M. J., «La Cámara de Castilla: Secretaría de Gracia y Justicia», en El tercer poder, Madrid, 1992, págs. 1-32; y CORTÉS ALONSO, V., «Los Consejos y su documentación: Historia, tratamiento y servicios», en Irargi, 1988, n. 1, págs. 165-247.

17 Periodizaciones generales de la historia de los archivos y de la archivística pueden verse en: BAUTIER, R. H., «Les archives», en SAMARAN, C. (Dir.), L'Histoire et ses méthodes, Brujas, 1961, págs. 1020-1166; SANDRI, L., «La Storia degli Archivi», en Rasegna degli Archivi di Stato, 18, 1958, 
Siglo XIII hasta finales del siglo XV

- Primeros archivos reales y municipales fuera de los recintos eclesiásticos.

- Primeras normas que exigen la conservación de algunos documentos y la elaboración de registros.

- Extensión del notariado, regulación de sus archivos y aumento generalizado de la producción de documentos entre los no eclesiásticos.

- Primeras regulaciones de los procedimientos administrativos y judiciales y creciente burocratización de las instituciones.

Finales del siglo XV hasta mediados del siglo XVIII

- Generalización de los archivos, incluidos los privados entre las élites sociales.

- El archivo sólo posee todavía un valor funcional, por el hipotético interés jurídico-administrativo de los documentos que custodia.

- Primeros tratados técnicos de archivística, de paleografía y de diplomática.

- Las normas reguladoras de las instituciones públicas y de los procedimientos administrativos y judiciales empiezan a exigir la conservación de los documentos de trámite, no sólo de los constitutivos de derecho.

- Se regula el funcionamiento de los archivos de la Iglesia, que se abren a los investigadores.

\section{Mediados siglo XVIII-mediados siglo XIX}

- Al valor jurídico-administrativo de los archivos se le suma el patrimonial (sus fondos forman parte del Patrimonio Histórico) y el científico (sus fondos son la base de la nueva historia científica).

- Aparición de los primeros archivos puramente históricos.

págs. 109-134; y LODOLINI, E., Lineamenti di storia de'll archivistica italiana. Dalle origini alla metá del secolo XX, Roma, 1991. Aportaciones españolas en CRUZ MUNDET, J. R., Manual de Archivística, Madrid, 1999, págs. 22-54; RODRÍGUEZ DE DIEGO, J. L., «Archivos del poder, archivos de la Administración, archivos de la Historia», en GENERELO, J. J. y MORENO, A. (Coords.), Historia de los archivos y de la archivística en España, Valladolid, 1998, págs. 29-42; VIVAS MORENO, A., «El tiempo de la archivística: un estudio de sus espacios de racionalidad histórica», en Brasilia, 33/3, 2004, págs. 76-96; MENDO CARMONA, C., «El largo camino de la archivística: de práctica a ciencia», en Signo, n. ${ }^{2}$ 2, 1995 , págs. 113-132; id., "Los archivos y la archivística: Evolución histórica y actualidad», en RUIZ RODRÍGUEZ, A. A., Manual de Archivística, Madrid, 1995, págs. 19-38; y ZOZAYA MONTES, L., «Una revisión de las periodizaciones archivísticas de la Edad Moderna», en Documenta \& Instrumenta, n. ${ }^{\circ} 6,2008$, págs. 119-145. 
- Primera configuración científica de la archivística.

- Fundación de las primeras entidades dedicadas a gestionar la política archivística del Estado.

- Apertura de los archivos a la investigación.

Mediados del siglo XIX-1977

- Profesionalización de los archiveros.

- Configuración de la red de archivos públicos españoles.

- La legislación sobre Patrimonio Histórico protege también a los fondos archivísticos.

- Consolidación científica de la archivística.

\section{CRONOLOGÍA}

\begin{tabular}{c|l} 
Año & Noticia \\
\hline 1200 & $\begin{array}{l}\text { Durante el siglo XIII se produce la extensión de las escrituras góticas } \\
\text { cursivas por España. Hacia 1200, los documentos que expide la } \\
\text { Cancillería Real castellana son la carta plomada, la carta abierta, el } \\
\text { privilegio rodado y el mandato }\end{array}$ \\
\hline 1200 & $\begin{array}{l}\text { Inicio de las primeras series de protocolos conservadas en el Archi- } \\
\text { vo de Gerona }\end{array}$ \\
\hline 1201 & Primeras noticias sobre la existencia de notarios en Tarazona \\
\hline 1206 & $\begin{array}{l}\text { El rey Pedro II de Aragón concede una notaría pública para el mu- } \\
\text { nicipio de Camprodón, la primera notaría real de la que se tiene } \\
\text { noticia en España. }\end{array}$ \\
\hline 1210 & $\begin{array}{l}\text { Noticias sobre la existencia de un notario en la Abadía de Sant Cu- } \\
\text { gat }\end{array}$ \\
\hline 1230 & $\begin{array}{l}\text { Jaime I implanta el notariado en Mallorca } \\
\text { Los escribas del concejo de Pamplona suscriben los documentos } \\
\text { como «notarios». }\end{array}$ \\
\hline 1232 & $\begin{array}{l}\text { Inicio de las primeras series de protocolos notariales conservadas en } \\
\text { los archivos de Mallorca y Barcelona }\end{array}$ \\
\hline 1232 & $\begin{array}{l}\text { Alfonso X establece en el Fuero de Murcia que los escribanos es- } \\
\text { criturarán íntegros en sus registros los documentos que otorguen }\end{array}$ \\
\hline
\end{tabular}




\begin{tabular}{|c|c|}
\hline Año & ticia \\
\hline 1234 & $\begin{array}{l}\text { Publicación de los Decretales o Extravagantes de Gregorio IX, pri- } \\
\text { mera recopilación de leyes canónicas - práctica que será imitada } \\
\text { más tarde por las cancillerías reales-, incluyendo disposiciones } \\
\text { sobre la expedición y conservación de los documentos }\end{array}$ \\
\hline 1238 & $\begin{array}{l}\text { Las Cortes de Valencia establecen que los notarios que falsifiquen } \\
\text { documentos perderán el oficio y todos sus bienes }\end{array}$ \\
\hline 1238 & $\begin{array}{l}\text { Las Cortes de Valladolid establecen que los falsificad } \\
\text { y de documentos serán desterrados y todos sus biene }\end{array}$ \\
\hline 1240 & Jaime \\
\hline 1247 & $\begin{array}{l}\text { El Fuero de Valencia obliga a los notarios a conservar las minutas de } \\
\text { los documentos que escrituren }\end{array}$ \\
\hline 1247 & $\begin{array}{l}\text { La Compilación de Huesca regula la función del notariado en Ara- } \\
\text { gón. Se establece la obligación de conservar registros de los docu- } \\
\text { mentos que expidan }\end{array}$ \\
\hline 1252 & Jaime I de Aragón crea el primer Registro de Cancillería de España \\
\hline 1252 & $\begin{array}{l}\text { La Cancillería de Alonso X el Sabio (1252-1284) comienza a expedir } \\
\text { documentos en castellano }\end{array}$ \\
\hline 1255 & $\begin{array}{l}\text { Fuero Real de Castilla regula las notarías y obliga a los escriba- } \\
\text { a conservar registros de minutas }\end{array}$ \\
\hline $1256-1265$ & $\begin{array}{l}\text { Alfonso X, en las Partidas, ordena la creación de un Registro en la } \\
\text { Cancillería Real y a los escribanos a archivar las minutas de los do- } \\
\text { cumentos que expidan. Se ponen las bases para la instrucción de } \\
\text { los procedimientos judiciales mediante sumarios escritos. La Terce- } \\
\text { ra Partida establece el procedimiento judicial, que tras diversas re- } \\
\text { formas perdurará hasta el siglo XIX. Se establece también que cuan- } \\
\text { do un escribano fallezca, las justicias de la localidad confiscarán } \\
\text { su archivo hasta que sea designado su sucesor }\end{array}$ \\
\hline 1260 & El Especulo de Castilla regula las minutas y los registros notariales \\
\hline 1274 & $\begin{array}{l}\text { Las Cortes de Zamora exigen a los escribanos que en los juicios es- } \\
\text { crituren también las «remembranzas», esto es, los documentos de } \\
\text { instrucción del procedimiento o sumarios }\end{array}$ \\
\hline 1278 & $\begin{array}{l}\text { Pedro III de Aragón prohíbe ejercer como notarios a quienes no hu- } \\
\text { biesen obtenido previamente una licencia }\end{array}$ \\
\hline A & $\begin{array}{l}\text { Durante el reinado de Fernando IV de Castilla desaparece el mal } \\
\text { dato como tipo documental }\end{array}$ \\
\hline
\end{tabular}




\begin{tabular}{|c|c|}
\hline Año & Noticia \\
\hline 1283 & $\begin{array}{l}\text { Las Cortes de Valencia establecen que los notarios que exijan pagos } \\
\text { superiores a los permitidos perderán su oficio }\end{array}$ \\
\hline 1285 & $\begin{array}{l}\text { Inicio de las primeras series de protocolos notariales conservadas en } \\
\text { Valencia }\end{array}$ \\
\hline 1287 & $\begin{array}{l}\text { El fuero de Tortosa prohíbe sacar de la ciudad las minutas de los no- } \\
\text { tarios que fallezcan o se trasladen }\end{array}$ \\
\hline 1287 & $\begin{array}{l}\text { Alfonso III de Aragón confisca las notarías de todos los que estaban } \\
\text { trabajando sin licencia }\end{array}$ \\
\hline 1289 & $\begin{array}{l}\text { Alfonso III de Aragón regula en las Cortes de Monzón el sistema de } \\
\text { examen que habrán de superar los aspirantes a notarios }\end{array}$ \\
\hline 1293 & $\begin{array}{l}\text { Sancho IV, en las Cortes de Valladolid, regulan el nombramiento y la } \\
\text { remuneración de los notarios reales en la Corte y en los concejos }\end{array}$ \\
\hline 1295 & $\begin{array}{l}\text { Las Cortes de Valladolid, bajo Fernando IV, establecen que los se- } \\
\text { llos de Corte permanecerán en manos de dos notarios legos, uno } \\
\text { para Castilla y otro para León, y que el oficio de Canciller no podrá } \\
\text { ser arrendado. Éstos Notarios Mayores se responsabilizarán de cus- } \\
\text { todiar los libros del Registro del Sello }\end{array}$ \\
\hline 1297 & $\begin{array}{l}\text { Las Cortes de Barcelona obligan a los notarios a conservar las mi- } \\
\text { nutas de los documentos que escrituren }\end{array}$ \\
\hline 1298 & $\begin{array}{l}\text { Elaboración de la recopilación de derecho canónico Liber Sextus, de } \\
\text { Bonifacio VIII, que incluye disposiciones sobre los archivos ecle- } \\
\text { siásticos }\end{array}$ \\
\hline 1299 & $\begin{array}{l}\text { Las Cortes de Valladolid acuerdan que los Notarios Mayores de } \\
\text { Castilla y León se responsabilizarán de la custodia de la documen- } \\
\text { tación real }\end{array}$ \\
\hline 1300 & $\begin{array}{l}\text { Las Cortes de Zaragoza autorizan a que el rey establezca el núme- } \\
\text { ro de notarios que habrá en el Reino. Se examinará previamente a } \\
\text { quienes deseen ejercer como notarios reales }\end{array}$ \\
\hline 1301 & $\begin{array}{l}\text { Las Cortes de Burgos prohíben que los clérigos ejerzan como nota- } \\
\text { rios }\end{array}$ \\
\hline 1302 & Jaime II de Aragón prohíbe que los eclesiásticos sean notarios \\
\hline 1308 & $\begin{array}{l}\text { Jaime II traslada el archivo real del Monasterio de San Juan de Si- } \\
\text { jena al Monasterio de San Juan de Jerusalén, en Barcelona, aunque } \\
\text { permanecen otros fondos dispersos por varios monasterios }\end{array}$ \\
\hline
\end{tabular}




\begin{tabular}{c|l} 
Año & Noticia \\
\hline 1310 & $\begin{array}{l}\text { Se publican las Leyes de Estilo, reguladoras en buena medida del } \\
\text { sistema procesal castellano y que desarrollan las Partidas. Habín } \\
\text { sido elaboradas entre 1265 y 1278 por Alfonso X y son un conjunto } \\
\text { de } 29 \text { leyes que se publicaron como «Declaraciones que hizo el rey } \\
\text { don Alfonso sobre las dudas que eran en el Fuero de las Leyes y su- } \\
\text { plicaciones e peticiones que ficieron al rey» }\end{array}$ \\
\hline 1311 & Edición de las Constituciones Clementinae eclesiásticas \\
\hline 1312 & $\begin{array}{l}\text { La Cancillería de Alfonso XI de Castilla deja de utilizar las cartas plo- } \\
\text { madas y las cartas abiertas, que son sustituidas por la provisión real }\end{array}$ \\
\hline 1312 & $\begin{array}{l}\text { Las Cortes de Valladolid fijan la pena de muerte para quienes falsi- } \\
\text { fiquen sellos o cartas reales }\end{array}$ \\
\hline 1315 & $\begin{array}{l}\text { Inicio de las primeras series de protocolos notariales conservadas en } \\
\text { Orense y Huesca }\end{array}$ \\
\hline 1316 & $\begin{array}{l}\text { Inicio de las primeras series de protocolos notariales conservadas en } \\
\text { Zaragoza }\end{array}$ \\
\hline 1318 & Jaime II de Aragón funda el Archivo Real de Barcelona \\
\hline 1322 & $\begin{array}{l}\text { Alfonso XI de Castilla prohíbe a los notarios eclesiásticos otorgar do- } \\
\text { cumentos a los laicos }\end{array}$ \\
\hline 1325 & $\begin{array}{l}\text { Alfonso XI de Castilla establece el procedimiento para nombrar es- } \\
\text { cribanos públicos reales y municipales }\end{array}$ \\
\hline 1329 & $\begin{array}{l}\text { Las Cortes de Valladolid establecen que los notarios de los tribuna- } \\
\text { les elaborarán un libro-registro con los pleitos que tramiten }\end{array}$ \\
\hline 1339 & $\begin{array}{l}\text { Las Cortes de Madrid establecen que los archivos de los registros de } \\
\text { los escribanos que fallezcan o cesen serán entregados a los alcaldes } \\
\text { de la población }\end{array}$ \\
\hline $\begin{array}{l}\text { Pedro IV de Aragón dicta unas ordenanzas para el Archivo Real de } \\
\text { Barcelona y nombra un archivero, Pere Perseya }\end{array}$ \\
\hline $\begin{array}{l}\text { Alfonso XI dicta el Ordenamiento de Alcalá, dedicado en buena par- } \\
\text { te a la regulación de los procedimientos judiciales }\end{array}$ \\
\hline $\begin{array}{l}\text { Pedro IV establece en las Cortes de Zaragoza que los notarios es- } \\
\text { criturarán íntegramente en sus registros los documentos que otor- } \\
\text { guen }\end{array}$
\end{tabular}




\begin{tabular}{|c|c|}
\hline Año & Noticia \\
\hline 1351 & $\begin{array}{l}\text { Pedro IV de Aragón prohíbe a los notarios catalanes sacar sus ar- } \\
\text { chivos de registros de la población donde residan }\end{array}$ \\
\hline 1360 & $\begin{array}{l}\text { El Concilio Provincial de Tarragona impone la obligación a todas las } \\
\text { parroquias de llevar un registro del cumplimiento por los fieles de los } \\
\text { sacramentos }\end{array}$ \\
\hline 1365 & $\begin{array}{l}\text { Las Cortes de Murviedro (Aragón) establecen que los archivos con } \\
\text { los registros de los notarios fallecidos serán entregados por sus he- } \\
\text { rederos, en diez días, a las autoridades civiles de la localidad }\end{array}$ \\
\hline 1369 & $\begin{array}{l}\text { La Cancillería de Enrique II (1369-1379) introduce un nuevo tipo } \\
\text { documental, la carta misiva }\end{array}$ \\
\hline 1371 & $\begin{array}{l}\text { Las Cortes castellanas de Toro ordenan centralizar la documenta- } \\
\text { ción real dispersa en un único archivo, objetivo que no llega a cum- } \\
\text { plirse }\end{array}$ \\
\hline 1371 & $\begin{array}{l}\text { Las Cortes de Valladolid establecen que los oficiales públicos no po- } \\
\text { drán requisar los archivos de registros de los escribanos, quienes } \\
\text { por su parte deberán custodiarlos en un lugar conocido }\end{array}$ \\
\hline 1378 & $\begin{array}{l}\text { La Cancillería del Papa Urbano VI introduce un nuevo documento, } \\
\text { las litterae apostolica in forma brevis o «breves», una forma simplifi- } \\
\text { cada de las litterae o «letras apostólicas» que venían utilizándose } \\
\text { desde el siglo XII }\end{array}$ \\
\hline 1384 & Ordenanzas del Archivo Real de Barcelona \\
\hline 1385 & $\begin{array}{l}\text { Juan I reordena el Consejo Real, dotándole de letrados y estable- } \\
\text { ciendo la llamada «vía de cámara», origen del expediente adminis- } \\
\text { trativo actual }\end{array}$ \\
\hline 1406 & $\begin{array}{l}\text { La Cancillería de Juan II (1406-1454) comienza a usar un nuevo tipo } \\
\text { documental, la Real Cédula }\end{array}$ \\
\hline 1413 & $\begin{array}{l}\text { Las Ordenanzas del Consejo Real de Navarra establecen que los } \\
\text { notarios de Corte conservarán en un sumario todos los documentos } \\
\text { que genere cada pleito }\end{array}$ \\
\hline 1419 & $\begin{array}{l}\text { Se crea el Archivo Real de Valencia, con fondos de la Chancillería } \\
\text { Real, la Audiencia Real y el Maestre Racional }\end{array}$ \\
\hline 1419 & $\begin{array}{l}\text { Las Cortes de Valencia establecen que los protonotarios, escribanos } \\
\text { y secretarios de las audiencias judiciales elaboren y archiven un } \\
\text { registro de las Provisiones y cartas de justicia y gracia que expidan. } \\
\text { Se les obliga también a entregar los sumarios de los procesos ya } \\
\text { sentenciados en el Archivo Real }\end{array}$ \\
\hline
\end{tabular}




\begin{tabular}{c|l} 
Año & Noticia \\
\hline 1419 & $\begin{array}{l}\text { Las Cortes de Valladolid establecen que los notarios incluirán en sus } \\
\text { registros todos los documentos que elaboren para los procesos ju- } \\
\text { diciales }\end{array}$ \\
\hline 1419 & $\begin{array}{l}\text { Las Cortes de Valladolid establecen la pena de muerte para los fal- } \\
\text { sificadores de documentos públicos }\end{array}$ \\
\hline 1422 & $\begin{array}{l}\text { Las Cortes de Barcelona disponen que cualquiera pueda obtener co- } \\
\text { pias de los documentos custodiados en el Archivo Real, excepto } \\
\text { cuando el documento trate de asuntos relacionados con el Patrimo- } \\
\text { nio Real }\end{array}$ \\
\hline 1436 & $\begin{array}{l}\text { Hacia esta fecha comienza a emplearse la escritura cortesana en } \\
\text { Castilla, que era una escritura gótica minúscula cursiva. En Aragón } \\
\text { se empleará la llamada gótica cursiva aragonesa }\end{array}$ \\
\hline 1446 & $\begin{array}{l}\text { Las Cortes de Toledo acuerdan que toda la documentación real } \\
\text { histórica, dispersa por catedrales y monasterios, se reúna en Toledo, } \\
\text { objetivo que no llega a realizarse }\end{array}$ \\
\hline $1474-$ & $\begin{array}{l}\text { Las Cortes de Valencia establecen que los archivos con los registros } \\
\text { de los notarios fallecidos pasarán a manos de otro notario de la po- } \\
\text { blación }\end{array}$ \\
\hline 1452 & $\begin{array}{l}\text { Un escriba llamado García elabora en Alcalá de Henares el primer } \\
\text { documento conocido ejecutado con escritura humanística redonda } \\
\text { en Castilla. La escritura humanística, gestada en Italia, supondrá una } \\
\text { nueva reunificación gráfica en Europa frente a la diversificación de ti- } \\
\text { pos cursivos en que había degenerado la escritura gótica }\end{array}$ \\
\hline 1472 & $\begin{array}{l}\text { En las cortes de Calatayud, presididas por Juan II, se crea el Archi- } \\
\text { vo del Reino de Aragón } \\
\text { rodados y comienza a utilizar cartas de merced, cartas de privilegio } \\
\text { y cartas de privilegio y confirmación }\end{array}$ \\
\hline $\begin{array}{l}\text { Primer impreso conocido en España, el Sinodal de Aguilafuente, } \\
\text { Heidelberg impresor alemán establecido en Segovia, Johan Parix de }\end{array}$ \\
$\begin{array}{l}\text { Mediante Pragmática Real se decreta que todos los ayuntamientos } \\
\text { de Castilla deberán disponer de un archivo en un «arca de tres } \\
\text { Ilaves"», que se custodiará en el Ayuntamiento, con una llave en ma- } \\
\text { nos del escribano de concejo, otra de la justicia ordinaria y otra de } \\
\text { un regidor }\end{array}$ \\
\hline 1504
\end{tabular}




\begin{tabular}{c|l} 
Año & Noticia \\
\hline 1480 & $\begin{array}{l}\text { Pragmática estableciendo la exención de tasas aduaneras y alca- } \\
\text { balas al comercio e importación de impresos }\end{array}$ \\
\hline 1484 & $\begin{array}{l}\text { La Cancillería del Papa Inocencio VIII (1484-1492) comienza a utili- } \\
\text { zar un nuevo tipo documental, el «motupropio» o motu proprio }\end{array}$ \\
\hline 1484 & $\begin{array}{l}\text { Alonso Díaz de Montalvo publica en Huete una recopilación de leyes } \\
\text { titulada Ordenanzas reales de Castilla por las cuales se han de librar } \\
\text { todos los pleitos civiles e criminales }\end{array}$ \\
\hline 1485 & $\begin{array}{l}\text { Las ordenanzas de la Chancillería de Valladolid establecen la crea- } \\
\text { ción de un archivo para sus fondos }\end{array}$ \\
\hline 1489 & $\begin{array}{l}\text { Una Pragmática Real ordena que toda la documentación real dis- } \\
\text { persa se envíe al archivo de la Chancillería de Valladolid }\end{array}$ \\
\hline 1499 & $\begin{array}{l}\text { Las ordenanzas municipales de Baeza establecen que se elaborará } \\
\text { un libro con las ordenanzas, privilegios y rentas de la ciudad, que se } \\
\text { guardará en un arca de tres llaves }\end{array}$ \\
\hline 1500 & $\begin{array}{l}\text { Los Reyes Católicos dictan la Pragmática Ordenanzas por la orden } \\
\text { ebrevedad de los pleitos, modificando el sistema procesal para ha- } \\
\text { cer más ágiles los embargos por deudas }\end{array}$ \\
\hline 1500 & $\begin{array}{l}\text { Los Capítulos de Corregidores obligan a éstos a disponer de un ar- } \\
\text { chivo en un «arca de tres llaves» con los sumarios instruidos por su } \\
\text { tribunal, que estará bajo la supervisión de un escribano }\end{array}$ \\
\hline $\begin{array}{l}\text { Durante el siglo XVI aparece la escritura bastarda española, una va- } \\
\text { riante local de la minúscula cursiva humanística }\end{array}$ \\
\hline $\begin{array}{l}\text { Mediante Pragmática Real se establece que los escribanos de con- } \\
\text { cejo deberán mantener dos libros encuadernados en papel de mar- } \\
\text { ca mayor, uno con copias de los privilegios y sentencias relativas al } \\
\text { concejo y otro con las cartas reales recibidas. En el archivo se con- } \\
\text { servarán también varias obras de referencia sobre el derecho real: } \\
\text { las Partidas, el Fuero Real, las Ordenanzas Reales de Castilla y al- } \\
\text { guna otra recopilación }\end{array}$ \\
\hline $\begin{array}{l}\text { Los Ren y la forma que se debe guardar en los juicios, reiterando la or- } \\
\text { den de que los sumarios deberán instruirse por escrito }\end{array}$ \\
$\begin{array}{l}\text { Una Pragmática establece que los archivos de expedientes con- } \\
\text { mueran, no se entregarán a su sucesor, sino que se archivarán y en- } \\
\text { viarán al Archivo de la Chancillería de Valladolid }\end{array}$ \\
\hline 1500
\end{tabular}




\begin{tabular}{|c|c|}
\hline Año & Noticia \\
\hline 1502 & $\begin{array}{l}\text { Pragmática estableciendo la censura previa de los impresos que } \\
\text { se editen en Castilla, se habilita para realizarla a los presidentes de } \\
\text { las dos chancillerías, a los Arzobispados de Sevilla, Toledo y Gra- } \\
\text { nada y a los obispos de Burgos, Salamanca y Zamora }\end{array}$ \\
\hline 1502 & $\begin{array}{l}\text { Mediante Pragmática Real se establece que el Canciller Mayor no } \\
\text { sellará ninguna carta real si previamente no ha sido registrada }\end{array}$ \\
\hline 1503 & $\begin{array}{l}\text { La Pragmática de Escribanos ordena que éstos deberán conservar } \\
\text { un registro encuadernado con copia íntegra de los documentos que } \\
\text { escrituren, origen de los actuales archivos de protocolos }\end{array}$ \\
\hline 1503 & $\begin{array}{l}\text { Jean Chappuis edita en París la recopilación de derecho canónico } \\
\text { Corpus iuris canonicis, vigente en gran medida hasta el siglo XX, y } \\
\text { que contiene varias normas sobre los archivos eclesiásticos }\end{array}$ \\
\hline 1503 & $\begin{array}{l}\text { Las Cortes de Barcelona establecen que los procesos concluidos de } \\
\text { los escribanos de las audiencias reales que falleciesen serán archi- } \\
\text { vados en ellas, bajo la autoridad de los «priores» de escribanos }\end{array}$ \\
\hline 1503 & $\begin{array}{l}\text { Las Cortes de Barcelona ordenan que todos los registros anteriores } \\
\text { a } 1493 \text { serán llevados al Archivo Real, los posteriores permanecerán } \\
\text { en manos de protonotarios y secretarios }\end{array}$ \\
\hline 1509 & $\begin{array}{l}\text { El rey Fernando nombra un archivero para la Chancillería de Valla- } \\
\text { dolid }\end{array}$ \\
\hline 1510 & $\begin{array}{l}\text { Las Cortes de Monzón ordenan que los protonotarios y secretarios } \\
\text { deberán remitir cada dos años sus registros de documentos al Ar- } \\
\text { chivo Real de Barcelona }\end{array}$ \\
\hline 1510 & $\begin{array}{l}\text { Las Cortes de Monzón establecen las tasas a cobrar por los archi- } \\
\text { veros del Archivo Real de Barcelona por expedir copias de los do- } \\
\text { cumentos que custodian }\end{array}$ \\
\hline 1510 & $\begin{array}{l}\text { Las Cortes de Monzón establecen que los doctores del Consejo } \\
\text { Real deberán mantener actualizado un libro-registro, en el que es- } \\
\text { tarán asentadas las causas que estén instruyendo }\end{array}$ \\
\hline 1510 & $\begin{array}{l}\text { Las Cortes de Monzón establecen el sistema de archivo para los } \\
\text { «procesos de Cortes»: los del brazo eclesiástico se enviarán a la Ca- } \\
\text { tedral de Tarragona, los del brazo militar a la Casa de la Diputación } \\
\text { y los del brazo real a la Casa de la Ciudad de Barcelona }\end{array}$ \\
\hline 1513 & $\begin{array}{l}\text { Las Cortes de Pamplona establecen que los archivos con los regis- } \\
\text { tros de los notarios que fallezcan serán entregados a otro notario de } \\
\text { la población, salvo que el difunto tuviese un heredero que también } \\
\text { fuese notario }\end{array}$ \\
\hline
\end{tabular}




\begin{tabular}{|c|c|}
\hline Año & Noticia \\
\hline 1525 & $\begin{array}{l}\text { En las Ordenanzas de la Audiencia de Sevilla (Libro } 2 .^{\circ} \text { ), se esta- } \\
\text { blece la organización del archivo de los sumarios judiciales }\end{array}$ \\
\hline 1526 & $\begin{array}{l}\text { En las Ordenanzas de la Chancillería de Granada (Libro II), se es- } \\
\text { tablece la organización del archivo de los sumarios judiciales }\end{array}$ \\
\hline 1526 & $\begin{array}{l}\text { Las Ordenanzas de Avellaneda (Navarra) ordenan a los notarios } \\
\text { incluir copia íntegra en sus registros de los documentos que expi- } \\
\text { dan }\end{array}$ \\
\hline 1528 & $\begin{array}{l}\text { Las Cortes de Monzón establecen las responsabilidades de los no- } \\
\text { tarios de las audiencias en el caso de extravío de los sumarios que } \\
\text { se custodian en sus archivos }\end{array}$ \\
\hline 1528 & $\begin{array}{l}\text { Carlos I, al salir de la Península, dicta unas Instrucciones para los } \\
\text { asuntos de cámara, que son la primera vez que se documenta por- } \\
\text { menorizadamente el procedimiento a seguir en la tramitación de un } \\
\text { expediente administrativo }\end{array}$ \\
\hline 1528 & $\begin{array}{l}\text { Las Cortes de Valencia establecen que las autoridades judiciales de } \\
\text { cada población inspeccionarán, una vez al año, los archivos de pro- } \\
\text { tocolos de sus notarías }\end{array}$ \\
\hline 1533 & $\begin{array}{l}\text { Las Cortes de Monzón establecen la obligación de custodiar en los } \\
\text { archivos reales los procesos instruidos ante el Justicia de Aragón }\end{array}$ \\
\hline 1534 & $\begin{array}{l}\text { Los escribanos que no encuadernen sus registros o no los firmen se- } \\
\text { rán sancionados con un año de suspensión de su oficio }\end{array}$ \\
\hline 1534 & $\begin{array}{l}\text { Las Cortes de Madrid establecen que los notarios que vendan o } \\
\text { arrienden sus oficios entregarán el archivo de sus registros al nuevo } \\
\text { escribano }\end{array}$ \\
\hline 1536 & $\begin{array}{l}\text { Las Ordenanzas del Consejo Real de Navarra establecen que los } \\
\text { notarios del Consejo conservarán los sumarios judiciales que ins- } \\
\text { truyan, encuadernados, en su archivo }\end{array}$ \\
\hline 1537 & $\begin{array}{l}\text { Las Cortes de Monzón establecen que los registros de las sen- } \\
\text { tencias de la Audiencia Real de Valencia y las cuentas del Maestre } \\
\text { Racional serán remitidos cada dos años al Archivo Real de Va- } \\
\text { lencia }\end{array}$ \\
\hline 1540 & Se funda el Archivo de Simancas por Carlos I \\
\hline 1542 & $\begin{array}{l}\text { Las Cortes de Monzón establecen que las audiencias llevarán un li- } \\
\text { bro-registro donde se asentarán todas las denuncias que se pre- } \\
\text { senten ante el tribunal, el cual será de consulta pública y libre }\end{array}$ \\
\hline
\end{tabular}




\begin{tabular}{c|l} 
Año & Noticia \\
\hline 1542 & $\begin{array}{l}\text { Las Ordenanzas del Consejo Real de Navarra ordenan que con los } \\
\text { procesos concluidos de la Cámara de Comptos se forme un archivo, } \\
\text { en el que también se custodiará un arca con las leyes y ordenanzas } \\
\text { del Reino }\end{array}$ \\
\hline 1542 & $\begin{array}{l}\text { Las Ordenanzas del Consejo Real de Navarra establecen que cuan- } \\
\text { do fallezca algún secretario o escribano del Consejo Real, los alcal- } \\
\text { des de Corte confiscarán su archivo y lo ubicarán en lugar seguro. } \\
\text { Prohíben también que se saquen documentos originales del archivo } \\
\text { de la Cámara de Comptos }\end{array}$ \\
\hline 1542 & $\begin{array}{l}\text { Las Cortes de Monzón establecen que los notarios escriturarán los } \\
\text { testamentos y codicilos en lengua romance }\end{array}$ \\
\hline 1548 & $\begin{array}{l}\text { Las Cortes de Valladolid establecen que los archivos de los escri- } \\
\text { banos muertos para quienes no se designe sucesor serán enviados } \\
\text { al archivo del concejo }\end{array}$ \\
\hline 1551 & $\begin{array}{l}\text { La Inquisición publica en España el primer Índice de Libros Prohibi- } \\
\text { dos, copia del que había editado la Universidad de Lovaina }\end{array}$ \\
\hline 1554 & $\begin{array}{l}\text { La Inquisición edita el primer Índice de libros prohibidos elaborado } \\
\text { en España, y que conocemos como Índice de Valdés, en el que se } \\
\text { prohíben las traducciones de la Biblia y un elevado número de libros } \\
\text { de inspiración erasmista o considerados inmorales (como el Laza- } \\
\text { rillo) }\end{array}$ \\
\hline 1556 & $\begin{array}{l}\text { Ordenanzas de la Universidad de Mercaderes de Sevilla sobre la or- } \\
\text { ganización de su archivo }\end{array}$ \\
\hline 1556 & $\begin{array}{l}\text { Diego de Covarrubias y Leiva, Obispo de Ciudad Rodrigo y Presi- } \\
\text { dente del Consejo de Estado, publica Practicarum Quaestionum Li- } \\
\text { ber unicus, dedicado a explicar el procedimiento judicial }\end{array}$ \\
\hline $\begin{array}{l}\text { Ordenanzas del Consejo Real de Navarra sobre la organización de } \\
\text { su archivo }\end{array}$ \\
$\begin{array}{l}\text { Alejo Salgado Correa publica en Sevilla Libro nombrado regimiento } \\
\text { de jueces }\end{array}$ \\
\hline $\begin{array}{l}\text { Durante el reinado de Felipe II, la Cancillería Real deja de utilizar el } \\
\text { albalá real en sus comunicaciones }\end{array}$ \\
\hline $\begin{array}{l}\text { Pragmática regulando el sistema de censura previa, que se centra- } \\
\text { brerías y bibliotecas }\end{array}$ \\
\hline 1558 iza en
\end{tabular}




\begin{tabular}{|c|c|}
\hline Año & Noticia \\
\hline 1561 & $\begin{array}{l}\text { Felipe II designa dos archiveros para Simancas, uno experto en le- } \\
\text { yes y procedimientos administrativos y el otro en humanidades }\end{array}$ \\
\hline 1563 & $\begin{array}{l}\text { El Concilio de Trento establece la obligatoriedad de todas las parro- } \\
\text { quias de llevar un registro de matrimonios, defunciones, cumpli- } \\
\text { miento pascual, bautismos y velaciones. }\end{array}$ \\
\hline 1563 & $\begin{array}{l}\text { Las conclusiones del Concilio de Trento propician la aparición de los } \\
\text { Archivos Diocesanos (hasta entonces los documentos episcopales } \\
\text { solían permanecer en los Archivos Catedralicios) }\end{array}$ \\
\hline 1563 & $\begin{array}{l}\text { Gabriel de Monterroso Alvarado publica Práctica civil y criminal e ins } \\
\text { trucción de escribanos }\end{array}$ \\
\hline 1567 & $\begin{array}{l}\text { Las Cortes de Pamplona establecen que cuando un notario sustitu- } \\
\text { ya a otro fallecido, elaborará un inventario de su archivo }\end{array}$ \\
\hline 1569 & $\begin{array}{l}\text { Quejas de Diego de Ayala, archivero de Simancas, acerca de la } \\
\text { saturación del Archivo }\end{array}$ \\
\hline 1569 & $\begin{array}{l}\text { Felipe II nombra archivero para la Embajada de España en Roma a } \\
\text { Juan de Berzosa }\end{array}$ \\
\hline 1571 & $\begin{array}{l}\text { Las Ordenanzas del Consejo de Indias establecen la creación de un } \\
\text { archivo para la institución }\end{array}$ \\
\hline 1571 & $\begin{array}{l}\text { Las Ordenanzas del Consejo de Indias ordenan remitir al Archivo de } \\
\text { Simancas todos los documentos que no tengan uso, que enviará en } \\
\text { un arcón cerrado y sobre los que elaborará } 2 \text { inventarios de los legajos } \\
\text { que transfiera, uno para el Archivo de Simancas y otro para el Consejo } \\
\text { de Indias, de modo que pueda solicitar su remisión en el futuro }\end{array}$ \\
\hline 1572 & $\begin{array}{l}\text { Felipe II encarga a Juan de Herrera la rehabilitación del castillo de } \\
\text { Simancas para ampliar el archivo real preexistente }\end{array}$ \\
\hline 1572 & $\begin{array}{l}\text { Las Ordenanzas del Consulado de Burgos (art. 26) ordenan la cre- } \\
\text { ación de un archivo }\end{array}$ \\
\hline 1577 & $\begin{array}{l}\text { Los documentos que se saquen del archivo Real del Consejo de } \mathrm{Na} \text { - } \\
\text { varra no se entregarán nunca originales, sino que se darán copias }\end{array}$ \\
\hline 1583 & $\begin{array}{l}\text { Una Pragmática Real establece que los corregidores se responsa- } \\
\text { bilizarán personalmente de la seguridad del archivo de los escriba- } \\
\text { nos fallecidos }\end{array}$ \\
\hline 1583 & $\begin{array}{l}\text { Ordenanzas de la Audiencia de Sevilla. La Audiencia no podrá ex- } \\
\text { pedir Provisiones Reales ordenando al Archivo de Simancas que le } \\
\text { remita originales de documentos sin primero consultarlo con el Con- } \\
\text { sejo de Castilla. }\end{array}$ \\
\hline
\end{tabular}




\begin{tabular}{|c|c|}
\hline Año & ia \\
\hline 1583 & Gonzalo Suárez de la Paz publica Praxis ecclesiástica et secularis \\
\hline 1583 & $\begin{array}{l}\text { Publicación por la Inquisición de un nuevo Índice de libros prohibi- } \\
\text { dos, en el que se autorizan las traducciones parciales de la Biblia y } \\
\text { se suaviza la prohibición de libros }\end{array}$ \\
\hline 1585 & Se crea el Archivo del Consell de Mallorca \\
\hline 1585 & $\begin{array}{l}\text { Las Cortes de Monzón establecen que las autoridades civiles se en- } \\
\text { cargarán de la custodia de los archivos de los notarios que fallezcan }\end{array}$ \\
\hline 1585 & $\begin{array}{l}\text { Las Cortes de Monzón establecen que «para la custodia de todas las } \\
\text { escrituras del Reino» se nombre un notario con un sueldo de } 60 \text { li- } \\
\text { bras al año }\end{array}$ \\
\hline 1585 & $\begin{array}{l}\text { Las Cortes de Monzón-Binéfar fijan la pena de muerte para los no- } \\
\text { tarios que falsifiquen documentos }\end{array}$ \\
\hline 1585 & $\begin{array}{l}\text { Las Cortes de Monzón-Binéfar establecer } \\
\text { rarán los documentos judiciales en roman }\end{array}$ \\
\hline 1586 & $\begin{array}{l}\text { Las Cortes de Pamplona ordenan al Consejo Real que mantenga un } \\
\text { libro-registro de las mercedes, hidalguías y mayorazgos que se con- } \\
\text { cedan }\end{array}$ \\
\hline 1586 & $\begin{array}{l}\text { Felipe II establece, mediante Pragmática, cómo habrán de ser los } \\
\text { tratamientos de cortesía en las cartas y otros documentos }\end{array}$ \\
\hline 1588 & Felipe II dicta las primeras ordenanzas del Archivo de Simancas \\
\hline 150 & $\begin{array}{l}\text { El Papa Sixto } V \text { dicta un reglamento para los archivos eclesiásticos } \\
\text { en el que se regula la formación que habrán de tener los archiveros } \\
\text { de la Iglesia, se ordena la elaboración de registros sobre los docu- } \\
\text { mentos que custodian los archivos y se establecen normas sobre las } \\
\text { transferencias y salidas de documentos de los archivos }\end{array}$ \\
\hline 1593 & $\begin{array}{l}\text { Las Cortes de Tarazona ordenan la creación de un Archivo para las } \\
\text { Cortes de Aragón }\end{array}$ \\
\hline 1593 & $\begin{array}{l}\text { Las Cortes de Tarazona, tras la revuelta de Aragón contra Felipe II, } \\
\text { establecen un sistema de censura previa similar al castellano, con el } \\
\text { Presidente de la Audiencia Real y el Virrey como únicos autorizados } \\
\text { para conceder licencias de impresión }\end{array}$ \\
\hline 1595 & $\begin{array}{l}\text { Mediante unas Instrucciones, Felipe Il establece cómo habrá de ser } \\
\text { el formato de las cartas y otros documentos elevados a la Corte, obli- } \\
\text { gando a dejar un amplio margen a la izquierda, a agrupar los asun- } \\
\text { tos mediante asientos y a incluir un breve resumen o «relación» en } \\
\text { el encabezamiento. }\end{array}$ \\
\hline
\end{tabular}




\begin{tabular}{|c|c|}
\hline Año & ticia \\
\hline 1596 & $\begin{array}{l}\text { Las Ordenanzas de la Audiencia de Filipinas prevén la creación de } \\
\text { un archivo de sumarios judiciales y de un registro de cartas reales }\end{array}$ \\
\hline $1598-1621$ & $\begin{array}{l}\text { Se comienza a expedir el Real Decreto en folio aparte y con un for- } \\
\text { mulario preestablecido }\end{array}$ \\
\hline 1600 & $\begin{array}{l}\text { Francisco González de Torneo publica en Madrid Práctica de escri- } \\
\text { banos }\end{array}$ \\
\hline 1600 & $\begin{array}{l}\text { Durante la primera mitad del siglo XVII desaparecen las escrituras } \\
\text { góticas cursivas en España }\end{array}$ \\
\hline 1602 & Juan Hevia de Bolaños publica en Lima Curia Philipica \\
\hline 1603 & $\begin{array}{l}\text { Los archivos de los escribanos de cámara de los Consejos, Au- } \\
\text { diencias y Chancillerías que fallezcan o sean cesados se entregarán } \\
\text { a los presidentes de la entidad para que los custodien }\end{array}$ \\
\hline 1604 & $\begin{array}{l}\text { Las Cortes de Valencia ordenan que los escribanos se responsabi- } \\
\text { licen de la custodia de todos los sumarios que instruyan en cualquier } \\
\text { tribunal del Reino }\end{array}$ \\
\hline 1604 & $\begin{array}{l}\text { Las Ordenanzas de la Audiencia de Méjico ordenan la conservación } \\
\text { en su archivo de las cartas reales que reciba }\end{array}$ \\
\hline 1604 & $\begin{array}{l}\text { Las Cortes de Valladolid establecen que los notarios conservarán un } \\
\text { archivo con los sumarios encuadernados de los procesos judiciales } \\
\text { en que hayan participado }\end{array}$ \\
\hline 1607 & $\begin{array}{l}\text { Reorganización del archivo de la Chancillería de Valladolid, nom- } \\
\text { brándose un archivero por el rey y ordenando a los escribanos de la } \\
\text { audiencia que depositen los sumarios sentenciados en dicho archivo }\end{array}$ \\
\hline 1612 & $\begin{array}{l}\text { Alonso de Villadiego y Vascuñana publica en Valladolid Instrucción } \\
\text { política y práctica judicial, conforme al estilo de los consejos, Au- } \\
\text { diencias y Tribunales de Corte y otras justicias ordinarias }\end{array}$ \\
\hline 1618 & $\begin{array}{l}\text { Juan Muñoz publica en Madrid Práctica de procuradores para seguir } \\
\text { pleitos civiles y criminales }\end{array}$ \\
\hline 1621 & $\begin{array}{l}\text { Se publica el primer periódico en España, el Correo de Francia, } \\
\text { Flandes y Alemania, editado en Madrid }\end{array}$ \\
\hline $1626-1627$ & $\begin{array}{l}\text { La censura previa se extiende a los impresos editados por las uni- } \\
\text { versidades y las entidades eclesiásticas, autorizándose a los recto- } \\
\text { res y a los ordinarios de los Obispados a concederlas }\end{array}$ \\
\hline 1633 & $\begin{array}{l}\text { Real Cédula de Felipe IV ordenando la construcción de un «Archivo } \\
\text { General de la Corte» en Madrid, proyecto que no se llevará a cabo }\end{array}$ \\
\hline
\end{tabular}




\begin{tabular}{|c|c|}
\hline Año & Noticia \\
\hline 1634 & $\begin{array}{l}\text { Las Ordenanzas de la Audiencia de Sevilla (art. 32) establecen la } \\
\text { obligación de disponer de un archivo para los sumarios sentenciados }\end{array}$ \\
\hline 1635 & $\begin{array}{l}\text { Una Real Cédula obliga a la Audiencia de Quito a que se archiven } \\
\text { todas las cartas reales que reciba y a que elabore un Registro con } \\
\text { ellas }\end{array}$ \\
\hline 1636 & $\begin{array}{l}\text { Pragmática estableciendo el «papel sellado", como forma de cobrar } \\
\text { una tasa sobre todos los documentos públicos }\end{array}$ \\
\hline 1636 & $\begin{array}{l}\text { Las Ordenanzas del Consejo de Indias establecen: El Consejo ten- } \\
\text { drá un archivo con } 2 \text { llaves, una en manos de un oidor y otra en las } \\
\text { del secretario más antiguo (art. 64); elaborarán un libro-registro en el } \\
\text { que quedarán asentados todos los documentos que reciban o expi- } \\
\text { dan (art. 66); y que cuando se sature, se remitan los documentos a } \\
\text { Simancas (art. 67) }\end{array}$ \\
\hline 1637 & $\begin{array}{l}\text { Una Pragmática Real establece la organización del Archivo de la Au- } \\
\text { diencia Real de Valencia }\end{array}$ \\
\hline 1641 & $\begin{array}{l}\text { Se publica en Perpiñán la primera Gaceta o periódico de información } \\
\text { política }\end{array}$ \\
\hline 1646 & $\begin{array}{l}\text { Francisco Salgado de Somoza, Presidente del Consejo de Castilla, } \\
\text { publica en Valladolid Labyrintus creditorum concurrentiae }\end{array}$ \\
\hline 1648 & $\begin{array}{l}\text { Mediante Auto Acordado se establece que los corregidores embar- } \\
\text { garán los archivos de los obispos muertos o trasladados hasta que } \\
\text { llegue su sustituto para hacerse cargo de ellos y evitar así su dis- } \\
\text { persión }\end{array}$ \\
\hline 1652 & $\begin{array}{l}\text { Las Cortes de Pamplona ordenan a los secretarios y escribanos } \\
\text { del Consejo Real y a los de cualquier otro tribunal que elaboren un } \\
\text { registro de todos los documentos que expidan }\end{array}$ \\
\hline 1661 & $\begin{array}{l}\text { Comienza a editarse, por el impresor Juan Paredes, la Gaceta de } \\
\text { Madrid, origen del actual Boletín Oficial del Estado }\end{array}$ \\
\hline 1663 & $\begin{array}{l}\text { Una Real Cédula prohíbe a los archiveros del Archivo Real de Va- } \\
\text { lencia que entreguen documentos originales a particulares }\end{array}$ \\
\hline 1667 & $\begin{array}{l}\text { Manuel Fernández de Ayala Aulestia publica en Zaragoza Práctica y } \\
\text { formulario de la Real Chancillería de Valladolid }\end{array}$ \\
\hline 1671 & Jerónimo Fernández de Herrera publica Práctica criminal \\
\hline 1682 & $\begin{array}{l}\text { Inauguración del edificio que albergará el Archivo de la Chan } \\
\text { de Valladolid }\end{array}$ \\
\hline
\end{tabular}




\begin{tabular}{|c|c|}
\hline Año & Noticia \\
\hline 1684 & $\begin{array}{l}\text { Diego José Dormer, Cronista del Reino de Aragón, publica en Zara- } \\
\text { goza Informe sobre que el Cronista de Aragón no puede continuar } \\
\text { los Anales de su Corona sin reconocer los archivos reales }\end{array}$ \\
\hline 1712 & Se funda la Biblioteca Pública de Palacio, futura Biblioteca Nacional. \\
\hline 1716 & $\begin{array}{l}\text { Intento de crear un archivo real centralizado en Valencia con los fon- } \\
\text { dos de las instituciones anteriores a los Decretos de Nueva Planta, el } \\
\text { Virreinato y la Intendencia, habrá otros en } 1758 \text { y } 1770 \text {, pero no se } \\
\text { logrará hasta la fase } 1859-1868\end{array}$ \\
\hline 1716 & $\begin{array}{l}\text { Como consecuencia de los Decretos de Nueva Planta, el Consejo de } \\
\text { Castilla asume la censura de los impresos editados en la Corona de } \\
\text { Aragón, instaurándose en todo el sistema castellano }\end{array}$ \\
\hline 1717 & $\begin{array}{l}\text { Un Real Decreto prohíbe a los oficiales de la Corte llevarse ningún } \\
\text { documento a sus casas y ordena la transferencia a Simancas de los } \\
\text { que se encuentren en los archivos }\end{array}$ \\
\hline 1717 & $\begin{array}{l}\text { Real Orden ordenando al Consejo de Castilla que transfiera a Si- } \\
\text { mancas todos los documentos sin uso que permanecen el los ar- } \\
\text { chivos de los Consejos }\end{array}$ \\
\hline 1717 & $\begin{array}{l}\text { Se establece el «depósito legal», obligando a todos los impresores a } \\
\text { entregar tres libros en la Corte, uno para la Biblioteca Real, otro para } \\
\text { la de El Escorial y otro para el Gobernador del Consejo de Castilla }\end{array}$ \\
\hline 1719 & $\begin{array}{l}\text { El Ayuntamiento de Madrid contrata a un experto en escrituras anti- } \\
\text { guas para copiar los pergaminos medievales de su Archivo Munici- } \\
\text { pal, que resultaban ilegibles }\end{array}$ \\
\hline 1721 & $\begin{array}{l}\text { Se crea el oficio de Superintendente General de los archivos de las } \\
\text { Ordenes militares, que dependía de la Corona }\end{array}$ \\
\hline 1723 & $\begin{array}{l}\text { Gaspar Ezpeleta Mallol publica en Madrid Práctica de secretarios } \\
\text { que contiene una concisa explicación de las calidades de este em- } \\
\text { pleo, distinción de las cartas misivas y declaración de las circunstan- } \\
\text { cias principales de que deben constar para tenerse por bien escritas }\end{array}$ \\
\hline 1724 & $\begin{array}{l}\text { Constitución Maxima vigilantia, expedida por el Papa, en la que se } \\
\text { regulan los archivos eclesiásticos, que por primera vez admiten la } \\
\text { posibilidad de permitir el acceso a los investigadores: se crean los } \\
\text { «archivos secretos», que no podrán ser consultados por particulares } \\
\text { sin autorización expresa del Obispo de la diócesis; se ordena la } \\
\text { confección de inventarios y catálogos de los documentos custodia- } \\
\text { dos en los archivos; y se establece la formación que deberían tener } \\
\text { los archiveros de la Iglesia }\end{array}$ \\
\hline
\end{tabular}




\begin{tabular}{|c|c|}
\hline Año & a \\
\hline 1724 & $\begin{array}{l}\text { Las Cortes de Estella establecen la organización del Archivo Real de } \\
\text { Navarra }\end{array}$ \\
\hline 1726 & $\begin{array}{l}\text { Informe de Santiago Agustín Riol, Oficial Mayor de la Secretaría } \\
\text { del Patronato Real, sobre el estado de los archivos reales: Noticia } \\
\text { general de todos los archivos y papeles pertenecientes a los Con- } \\
\text { sejos y Audiencias de España }\end{array}$ \\
\hline 1727 & $\begin{array}{l}\text { Se crea la primera plaza de archivero en la Corte, en la Secretaría } \\
\text { de Despacho del Consejo de Estado, con un salario anual de } 25.000 \\
\text { reales. }\end{array}$ \\
\hline 1729 & $\begin{array}{l}\text { Se crea el Cuerpo de revisores de firmas y documentos para su pe- } \\
\text { ritación }\end{array}$ \\
\hline 1738 & $\begin{array}{l}\text { Se funda la Real Academia de la Historia, que pronto se dotará de } \\
\text { un archivo con documentos históricos y de su correspondiente ar- } \\
\text { chivero }\end{array}$ \\
\hline 1738 & $\begin{array}{l}\text { Cristóbal Rodríguez publica en Madrid Biblioteca universal de la } \\
\text { Polygraphia española }\end{array}$ \\
\hline 1738 & Real Orden por la que se reorganiza el Archivo Real de Barcelona \\
\hline 1739 & $\begin{array}{l}\text { José Campillo y Cossío, Secretario de Estado de Hacienda, escribe } \\
\text { Inspección de las seis Secretarías de Estado y calidades y circuns- } \\
\text { tancias que deben concurrir en sus respectivos secretarios }\end{array}$ \\
\hline 1740 & $\begin{array}{l}\text { Francisco J. de Garma es nombrado archivero del Archivo Real de } \\
\text { Barcelona }\end{array}$ \\
\hline 1748 & $\begin{array}{l}\text { El Ayuntamiento de Madrid contrata a un nuevo archivero-paleó- } \\
\text { grafo para que copie los documentos antiguos y ordene el archivo } \\
\text { municipal. Al año siguiente se le contratará un ayudante }\end{array}$ \\
\hline 1749 & $\begin{array}{l}\text { A iniciativa del marqués de la Ensenada, se crea una comisión de ar- } \\
\text { chivos, dirigida por el ministro Carvajal, con el fin de formar una } \\
\text { Colección Diplomática Real de España }\end{array}$ \\
\hline 1749 & $\begin{array}{l}\text { «Viaje literario» de Andrés Marcos Burriel, financiado por el Marqués } \\
\text { de la Ensenada, en el que recopila } 13.664 \text { documentos que deposi- } \\
\text { ta en la Academia de la Historia }\end{array}$ \\
\hline 1751 & Se crea la plaza de archivero en la Secretaría de Guerra \\
\hline 1752 & $\begin{array}{l}\text { «Viaje literario» de Luis José de Velásquez, Marqués de Valdeflores, } \\
\text { financiado por el Marqués de la Ensenada, en el que recopila } 62 \text { le- } \\
\text { gajos con documentos medievales y los deposita en la Real Acade- } \\
\text { mia de la Historia }\end{array}$ \\
\hline
\end{tabular}




\begin{tabular}{|c|c|}
\hline Año & Noticia \\
\hline 1752 & $\begin{array}{l}\text { El Padre Sarmiento escribe unas «Reflexiones sobre archivos y } \\
\text { otros asuntos de suma importancia» }\end{array}$ \\
\hline 1754 & $\begin{array}{l}\text { Intento fallido de crear un archivo en la Chancillería de Granada, le } \\
\text { seguirán otros intentos en } 1769 \text { y } 1799\end{array}$ \\
\hline 1754 & $\begin{array}{l}\text { Mediante Real Cédula, el Archivo Real de Barcelona recibe nuevas } \\
\text { ordenanzas y cambia su nombre por el de Archivo de la Corona de } \\
\text { Aragón }\end{array}$ \\
\hline 1755 & $\begin{array}{l}\text { Publicación por la Real Academia de la Historia de las Instrucciones } \\
\text { formadas para el reconocimiento de las antigüedades de España, } \\
\text { conocidas como Instrucciones de Ensenada }\end{array}$ \\
\hline 1755 & $\begin{array}{l}\text { El Padre Esteban de Terreros y Pando publica en Madrid Paleogra- } \\
\text { fía española o los diversos modos de escrituras que ha habido en } \\
\text { España desde Augusto César acá, sacados de varios originales y } \\
\text { expresados en diez y ocho láminas finas, cuya lectura podrá ayudar } \\
\text { al reconocimiento de archivos e inteligencia de los monumentos de } \\
\text { la antigüedad, con una breve historia del origen, ruina y restauración } \\
\text { de la lengua castellana }\end{array}$ \\
\hline 1758 & $\begin{array}{l}\text { Informe del Secretario de Estado Benito Martínez Gómez-Gayoso } \\
\text { sobre la conveniencia de dotar de plazas de archivero a todas las } \\
\text { entidades de la Corte }\end{array}$ \\
\hline 1759 & $\begin{array}{l}\text { Olivier Legipont publica en Valencia Itinerario en que se contiene el } \\
\text { modo de hacer con utilidad los viages a Cortes estrangeras con } \\
\text { dos disertaciones, la primera sobre el modo de ordenar y componer } \\
\text { una librería, la segunda sobre el modo de poner orden en un ar- } \\
\text { chivo }\end{array}$ \\
\hline 1762 & $\begin{array}{l}\text { Se crea la plaza de archivero en la Secretaría de Estado de Ha- } \\
\text { cienda }\end{array}$ \\
\hline 1762 & Carlos III convierte a la Gaceta de Madrid en propiedad del Estado \\
\hline 1762 & $\begin{array}{l}\text { Carlos III prohíbe a la Inquisición dictar edictos de secuestro de im- } \\
\text { presos sin autorización previa del rey }\end{array}$ \\
\hline 1763 & $\begin{array}{l}\text { Se crean las plazas de archivero en las secretarías de Estado de } \\
\text { Gracia y Justicia e Indias }\end{array}$ \\
\hline 1764 & $\begin{array}{l}\text { Real Cédula prohibiendo que se saquen libros o documentos origi- } \\
\text { nales de los archivos reales }\end{array}$ \\
\hline 1764 & $\begin{array}{l}\text { Francisco Elizondo Álvarez publica Práctica universal forense de } \\
\text { los tribunales de esta Corte: su origen, jurisdicción y negocios }\end{array}$ \\
\hline
\end{tabular}




\begin{tabular}{|c|c|}
\hline Año & $\mathbf{a}$ \\
\hline 1764 & $\begin{array}{l}\text { Antonio Martínez de Salazar, oidor del Consejo de Castilla, publica } \\
\text { en Madrid Colección de memorias y noticias del gobierno general y } \\
\text { político del Consejo }\end{array}$ \\
\hline 1764 & $\begin{array}{l}\text { Real Orden por la que Carlos III concede, por intermediación de } \\
\text { Ricardo Wall, a Francisco Pérez Bayer } 300 \text { doblones para la elabo- } \\
\text { ración de un índice de los manuscritos hebreos y latinos del Escorial }\end{array}$ \\
\hline 1765 & Se crea el primer Archivo de Protocolos Notariales en Madrid \\
\hline 1766 & $\begin{array}{l}\text { Se prohíbe, tras la supuesta participación del clero en el Motín con- } \\
\text { tra Esquilache, que las entidades eclesiásticas posean imprentas }\end{array}$ \\
\hline 1767 & $\begin{array}{l}\text { Expulsión de los Jesuitas de España. Sus archivos son incautados } \\
\text { por el Estado, dispersándose por diversos archivos }\end{array}$ \\
\hline 1767 & $\begin{array}{l}\text { Prohibición de imprimir pronósticos, romances de ciego y coplas de } \\
\text { ajusticiados }\end{array}$ \\
\hline 1768 & $\begin{array}{l}\text { Carlos III ordena la creación del Archivo General del Reino de Gali- } \\
\text { cia en la Audiencia Real }\end{array}$ \\
\hline 1769 & $\begin{array}{l}\text { Creación de las "Subdelegaciones de imprentas", que autorizaban } \\
\text { a los corregidores y a los presidentes de Audiencias y Chancillerías } \\
\text { a conceder licencias de impresión en sus distritos }\end{array}$ \\
\hline 1770 & $\begin{array}{l}\text { Real Orden Circular ordenando la fusión de los archivos de Valencia } \\
\text { (Real, Bailía, Cortes, Justicia Civil, Diputación, Gobernación y Tres- } \\
\text { cientos Sueldos) }\end{array}$ \\
\hline 1770 & Ordenanzas del Archivo Real del Virreinato de Nueva España \\
\hline 1773 & $\begin{array}{l}\text { Los eclesiásticos se someterán al mismo sistema de censura previa } \\
\text { que los editores laicos }\end{array}$ \\
\hline 1775 & Ordenanzas para el Archivo General del Reino de Galicia \\
\hline 1776 & $\begin{array}{l}\text { Las Ordenanzas de la Audiencia de Cuzco establecen que se ela- } \\
\text { borarán libros de registro de votaciones, reales cédulas y provisio- } \\
\text { nes, sentencias y de contabilidad. También regulan la organización } \\
\text { de su archivo }\end{array}$ \\
\hline 1778 & $\begin{array}{l}\text { Carlos III ordena que se recopilen los documentos importantes en los } \\
\text { archivos de la Casa de Contratación, el Consejo de Indias y Siman- } \\
\text { cas para escribir una historia de la colonización española en Améri- } \\
\text { ca. Será el origen de la fundación del Archivo General de Indias }\end{array}$ \\
\hline 1 & $\begin{array}{l}\text { Los impresores deberán seguir las normas ortográficas fijadas por la } \\
\text { Real Academia de la Lengua }\end{array}$ \\
\hline
\end{tabular}




\begin{tabular}{|c|c|}
\hline Año & Noticia \\
\hline 1779 & $\begin{array}{l}\text { El archivero de la Secretaría de Indias, Manuel José de Ayala, es- } \\
\text { cribe el Discurso sobre el arreglo de los archivos comprehendidos en } \\
45 \text { artículos }\end{array}$ \\
\hline 1779 & $\begin{array}{l}\text { Real Orden prohibiendo exportar al extranjero bienes artísticos y } \\
\text { culturales }\end{array}$ \\
\hline 1780 & $\begin{array}{l}\text { Andrés Merino de Jesucristo publica en Madrid Escuela de leer le- } \\
\text { tras cursivas antiguas y modernas desde la entrada de los godos en } \\
\text { España hasta nuestros días }\end{array}$ \\
\hline 1780 & $\begin{array}{l}\text { Las Cortes de Pamplona prohíben que los escribanos o procurado- } \\
\text { res saquen documentos originales de los archivos reales. }\end{array}$ \\
\hline 1780 & $\begin{array}{l}\text { Los escribanos de Cámara del Consejo de Castilla solicitan crear un } \\
\text { Archivo Central para los expedientes y sumarios que custodian }\end{array}$ \\
\hline 1781 & $\begin{array}{l}\text { Primer examen con concurso público para contratar un archivero } \\
\text { para el Ayuntamiento de Madrid; éste consistió en cuatro pruebas: } \\
\text { una disertación sobre cómo organizaría el candidato el archivo, una } \\
\text { traducción latina, una transcripción de documentos antiguos y un } \\
\text { ejercicio oral sobre siglas, abreviaturas y otros signos gráficos }\end{array}$ \\
\hline 1785 & $\begin{array}{l}\text { Creación del Archivo General de Indias con } 255 \text { legajos transferidos } \\
\text { desde Simancas }\end{array}$ \\
\hline 1785 & Supresión de impuestos para el papel destinado a las imprentas \\
\hline 1788 & $\begin{array}{l}\text { Las Instrucciones de Corregidores, dictadas este año, ordenan que } \\
\text { se investigue si realmente los ayuntamientos disponen de un archi- } \\
\text { vo ajustado a lo dispuesto en la ley }\end{array}$ \\
\hline 1788 & Primer reglamento sobre la edición de periódicos \\
\hline 1789 & $\begin{array}{l}\text { Requisa de toda publicación que contenga noticias sobre los suce- } \\
\text { sos de Francia }\end{array}$ \\
\hline 1790 & $\begin{array}{l}\text { Carlos IV dicta las ordenanzas del Archivo de Indias, que recogen el } \\
\text { principio del respeto al orden de procedencia por primera vez en Es- } \\
\text { paña }\end{array}$ \\
\hline 1790 & $\begin{array}{l}\text { El Padre Enrique Flórez publica en Madrid Clave historial con que se } \\
\text { abre la puerta a la historia eclesiástica y política, chronología de los } \\
\text { Papas y Emperadores, reyes de España, Italia y Francia con los orí- } \\
\text { genes de todas las monarquías: concilios, hereges, santos, escrito- } \\
\text { res y sucesos memorables de cada siglo }\end{array}$ \\
\hline 1790 & $\begin{array}{l}\text { Real Orden Circular reiterando la unificación de todos los archivos } \\
\text { reales de Valencia }\end{array}$ \\
\hline
\end{tabular}




\begin{tabular}{|c|c|}
\hline Año & Noticia \\
\hline 1790 & $\begin{array}{l}\text { Gaspar Melchor de Jovellanos elabora la «Instrucción para el arreglo } \\
\text { del archivo del Monasterio de Sancti Spiritus de Salamanca» }\end{array}$ \\
\hline 1791 & Se prohíben todos los periódicos, excepto la Gaceta de Madrid \\
\hline 1791 & Instrucciones para el fomento de la industria del papel en España \\
\hline 1792 & $\begin{array}{l}\text { «Viaje literario» de Joaquín Traggia por diversos monasterios ara- } \\
\text { goneses y catalanes recopilando diplomas medievales }\end{array}$ \\
\hline 1792 & $\begin{array}{l}\text { Se crea en la Real Academia de la Historia la «Comisión de Anti- } \\
\text { güedades» }\end{array}$ \\
\hline 1793 & $\begin{array}{l}\text { Se crea el Archivo del Virreinato de Nueva España en el castillo de } \\
\text { Chapultepec, dotándosele de las mismas ordenanzas que al de In- } \\
\text { dias. Tras la independencia se refundará como Archivo General de } \\
\text { la Nación }\end{array}$ \\
\hline 1794 & $\begin{array}{l}\text { Las Cortes de Pamplona establecen que para el sostenimiento del } \\
\text { Archivo Real, cada sumario que se envíe al archivo pagará una } \\
\text { tasa de } 2 \text { reales }\end{array}$ \\
\hline 1795 & $\begin{array}{l}\text { Manuel Abellá, con patrocinio de Manuel Godoy, publica en Madrid } \\
\text { «Noticia y plan de un viaje para reconocer archivos y formar la co- } \\
\text { lección diplomática de España» }\end{array}$ \\
\hline 1796 & $\begin{array}{l}\text { Real Orden autorizando aumentar las tasas que se exigen por las } \\
\text { copias de documentos del Archivo General del Reino de Valencia y } \\
\text { que el dinero obtenido se invierta en la mejora de sus instalaciones }\end{array}$ \\
\hline 1796 & $\begin{array}{l}\text { Pedro Escolano de Arrieta publica en Madrid Práctica del Consejo } \\
\text { Real en el despacho de los negocios consultivos, instructivos y con- } \\
\text { tenciosos }\end{array}$ \\
\hline 178 & $\begin{array}{l}\text { La Corona prohíbe la exportación de manuscritos, libros y obras de } \\
\text { arte del patrimonio nacional (ya prohibido en 1779) }\end{array}$ \\
\hline 1800 & $\begin{array}{l}\text { Ramón Lázaro de Dou y de Bassols publica en Madrid Instituciones } \\
\text { de derecho público de España, con noticia particular de Cataluña y } \\
\text { de las principales reglas de gobierno en cualquier Estado }\end{array}$ \\
\hline 1801 & $\begin{array}{l}\text { El Abate Lorenzo Hervás y Panduro publica en Cartagena Descrip- } \\
\text { ción del Archivo de la Corona de Aragón y noticia del Archivo Ge- } \\
\text { neral de la Orden de Santiago en el Convento de Uclés }\end{array}$ \\
\hline 1 & $\begin{array}{l}\text { Se reexpide la Real Orden prohibiendo exportar al extranjero bienes } \\
\text { artísticos y culturales de } 1779\end{array}$ \\
\hline
\end{tabular}




\begin{tabular}{|c|c|}
\hline Año & Noticia \\
\hline 1803 & $\begin{array}{l}\text { Real Cédula elevando a la categoría de ley las Instrucciones para el } \\
\text { reconocimiento de las antigüedades de España de la Academia de la } \\
\text { Historia y ordenando que todas las antigüedades que se encuentren } \\
\text { se depositen en esta institución, lo que dará origen algún tiempo } \\
\text { después al Museo Arqueológico Nacional y al Archivo Histórico Na- } \\
\text { cional }\end{array}$ \\
\hline 1804 & $\begin{array}{l}\text { El Archivo de Bailía General, junto con el del Maestre Racional, } \\
\text { constituyen el Archivo General de Real Patrimonio, en Barcelona }\end{array}$ \\
\hline 1804 & $\begin{array}{l}\text { Joseph Marcos Gutiérrez publica en Madrid Práctica criminal de } \\
\text { España }\end{array}$ \\
\hline 1805 & $\begin{array}{l}\text { Las Ordenanzas de la Audiencia de Caracas establecen que llevarán } \\
\text { un registro de las cartas reales que reciban y de las sentencias que } \\
\text { emitan }\end{array}$ \\
\hline 1808 & Se funda el Archivo del Palacio Real de Madrid \\
\hline 1810 & $\begin{array}{l}\text { Se crea el Estado Mayor del Ejército, dotado con un archivo admi- } \\
\text { nistrativo }\end{array}$ \\
\hline 1810 & $\begin{array}{l}\text { El Consejo de Regencia suprime la censura previa y los tribunales } \\
\text { de imprentas (la censura previa será reimplantada y suprimida varias } \\
\text { veces a lo largo del siglo, según la orientación política de cada pe- } \\
\text { riodo) }\end{array}$ \\
\hline 1813 & $\begin{array}{l}\text { Se crea el Archivo de la Contaduría Mayor de Cuentas, por Decreto } \\
\text { de las Cortes Generales de Cádiz }\end{array}$ \\
\hline 1814 & $\begin{array}{l}\text { Próspero de Bofarull y Mascaró toma posesión de la plaza de archi- } \\
\text { vero del Archivo Real de Barcelona }\end{array}$ \\
\hline 1815 & $\begin{array}{l}\text { Fernando VII nombra archivero de Simancas a Tomás González y } \\
\text { ordena a la Embajada española en París que inicie las gestiones } \\
\text { para la recuperación de los documentos que el ejército francés robó } \\
\text { de Simancas }\end{array}$ \\
\hline 1818 & $\begin{array}{l}\text { Real Orden ordenando que en cada pueblo se hará un apeo de los } \\
\text { bienes inmuebles que existan y el documento se conservará en su } \\
\text { archivo municipal }\end{array}$ \\
\hline 1820 & Reglamento del Archivo de la Contaduría Mayor de Cuentas \\
\hline 1820 & $\begin{array}{l}\text { Los Jefes Políticos de las provincias harán inventarios de las bi- } \\
\text { bliotecas y archivos que están en manos del clero y custodiarán } \\
\text { los fondos }\end{array}$ \\
\hline
\end{tabular}




\begin{tabular}{c|l} 
Año & Noticia \\
\hline 1823 & $\begin{array}{l}\text { La Ley de Ayuntamientos establece que cada ayuntamiento deberá } \\
\text { disponer de un archivo, que estará bajo la responsabilidad del Se- } \\
\text { cretario Municipal. }\end{array}$ \\
\hline 1826 & $\begin{array}{l}\text { Parte de la documentación de las Secretarías de Estado (la anterior } \\
\text { a 1790) es transferida desde Madrid a Simancas, el resto terminará } \\
\text { en el Archivo Histórico Nacional años más tarde }\end{array}$ \\
\hline 1828 & $\begin{array}{l}\text { Comienzan a acceder a los fondos del Archivo General de Indias los } \\
\text { primeros investigadores privados }\end{array}$ \\
\hline 1828 & $\begin{array}{l}\text { Fernando VII visita el Archivo de la Corona de Aragón durante su es- } \\
\text { tancia en Barcelona }\end{array}$ \\
\hline 1834 & $\begin{array}{l}\text { Facundo Porras Huidobro publica en Madrid Disertación sobre ar- } \\
\text { chivos y reglas de su coordinación }\end{array}$ \\
\hline 1836 & $\begin{array}{l}\text { Mediante Real Decreto se suprimen los Consejos, las Chancillerías } \\
\text { y las Audiencias, creándose la nueva estructura judicial del Estado li- } \\
\text { beral, basada en partidos, audiencias provinciales y un Tribunal Su- } \\
\text { premo. Se ordena que en cada tribunal se cree un archivo con los } \\
\text { sumarios de lo procesos }\end{array}$ \\
\hline 1834 & $\begin{array}{l}\text { Tras suprimirse la Cámara de Castilla, sus fondos pasan al archivo } \\
\text { del Ministerio de Gracia y Justicia }\end{array}$ \\
\hline 1834 & $\begin{array}{l}\text { Al crearse el Consejo Real de España e Indias, éste se queda con } \\
\text { los archivos de la Escribanía de Gobierno, el Archivo Antiguo o Re- } \\
\text { servado del Consejo de Castilla y la Secretaría de Presidencia del } \\
\text { Consejo de Castilla }\end{array}$ \\
\hline 1835 & $\begin{array}{l}\text { Real Orden autorizando a la Real Academia de la Historia para que- } \\
\text { darse con todos los documentos y libros procedentes de las mo- } \\
\text { nasterios suprimidos que considerase valiosos }\end{array}$ \\
\hline $\begin{array}{l}\text { arnando Troche Zúñiga publica en La Coruña El archivo cronoló- } \\
\text { gico-topográfico }\end{array}$ \\
\hline $\begin{array}{l}\text { a Diputación de Navarra recibe el encargo de custodiar los fondos } \\
\text { de la extinta Cámara de Comptos, origen del Archivo General de Na- } \\
\text { varra }\end{array}$ \\
\hline $\begin{array}{l}\text { El archivo del Registro General del Sello posterior a 1690 queda en } \\
\text { son enviados a Simancas }\end{array}$ \\
\hline 1836
\end{tabular}




\begin{tabular}{|c|c|}
\hline Año & Noticia \\
\hline 1836 & $\begin{array}{l}\text { La Gaceta de Madrid se convierte en el diario oficial del Estado y se } \\
\text { establece que la publicación de una disposición en ella implicará su } \\
\text { entrada en vigor }\end{array}$ \\
\hline 1837 & $\begin{array}{l}\text { El 2. Decreto desamortizador establece, en su artículo XXV, que los } \\
\text { archivos y libros incautados a los establecimientos religiosos serán } \\
\text { enviados a los centros de instrucción pública de su provincia }\end{array}$ \\
\hline 1837 & $\begin{array}{l}\text { Se reexpide la Real Orden prohibiendo exportar al extranjero bienes } \\
\text { artísticos y culturales de } 1779\end{array}$ \\
\hline 1838 & $\begin{array}{l}\text { Informe de la Real Academia de la Historia al Ministerio de Gracia y } \\
\text { Justicia sobre qué conocimientos deberían tener los funcionarios } \\
\text { que trabajasen en los archivos históricos del Reino }\end{array}$ \\
\hline 1839 & $\begin{array}{l}\text { La Real Sociedad Económica Matritense financia la creación de la } \\
\text { primera cátedra de Paleografía española en la Universidad Com- } \\
\text { plutense }\end{array}$ \\
\hline 1840 & $\begin{array}{l}\text { Real Orden Circular ordenando la creación de comisiones de ex- } \\
\text { pertos que analicen y clasifiquen los fondos de los conventos supri- } \\
\text { midos }\end{array}$ \\
\hline 1841 & Se funda el Archivo General de Navarra \\
\hline 1844 & $\begin{array}{l}\text { Real Orden estableciendo la normativa para regular el acceso a los } \\
\text { archivos públicos. Será libre para los «puramente literarios», pero se } \\
\text { prohibirá la consulta de documentos históricos posteriores al año } \\
1700\end{array}$ \\
\hline 1844 & $\begin{array}{l}\text { Un Real Decreto establece que las Secretarías de Archivo de las Ca- } \\
\text { pitanías Generales pasarán a llamarse Secciones de Archivo }\end{array}$ \\
\hline 1844 & $\begin{array}{l}\text { Real Orden creando las Comisiones Provinciales de Monumentos, } \\
\text { que tendrán entre sus funciones el fomento de la fundación de ar- } \\
\text { chivos históricos y la conservación de los documentos antiguos }\end{array}$ \\
\hline 1844 & $\begin{array}{l}\text { El Archivo General de Simancas deja de recibir transferencias del } \\
\text { Estado, convirtiéndose en un archivo puramente histórico }\end{array}$ \\
\hline 1844 & $\begin{array}{l}\text { Se comienzan a admitir investigadores en el Archivo Municipal de } \\
\text { Madrid, previa instancia con su solicitud dirigida al alcalde }\end{array}$ \\
\hline 1847 & $\begin{array}{l}\text { Decreto ordenando la construcción de un Archivo General del Reino } \\
\text { en Alcalá de Henares }\end{array}$ \\
\hline 1847 & $\begin{array}{l}\text { Creación de las Juntas de Partido por el Ministerio de Gracia y Jus- } \\
\text { ticia para hacer efectiva la orden de crear un archivo en cada tribunal }\end{array}$ \\
\hline
\end{tabular}




\begin{tabular}{|c|c|}
\hline Año & Noticia \\
\hline 1847 & $\begin{array}{l}\text { Real Decreto por el que se funda el Archivo General del Ministerio } \\
\text { de Comercio, Instrucción y Obras Públicas }\end{array}$ \\
\hline 1847 & $\begin{array}{l}\text { Un Real Decreto establece la organización de los archivos del Mi- } \\
\text { nisterio de Gracia y Justicia }\end{array}$ \\
\hline 1847 & $\begin{array}{l}\text { Mediante Real Decreto se crea la Junta Superior Directiva de Ar- } \\
\text { chivos del Ministerio de Gracia y Justicia }\end{array}$ \\
\hline 1847 & $\begin{array}{l}\text { El archivero del Archivo de la Corona de Aragón, don Próspero de } \\
\text { Roparull y Mascaró edita la Colección de documentos inéditos del } \\
\text { Archivo de la Corona de Aragón, dedicado a los fondos medievales }\end{array}$ \\
\hline 1848 & $\begin{array}{l}\text { Real Orden estableciendo la creación de Juntas Subalternas de Ar- } \\
\text { chivos del Ministerio de Gracia y Justicia en provincias }\end{array}$ \\
\hline 1848 & $\begin{array}{l}\text { Real Decreto suprimiendo la Junta Superior Directiva de Archivos del } \\
\text { Ministerio de Gracia y Justicia y creando la Dirección General de Ar- } \\
\text { chivos de España y Ultramar }\end{array}$ \\
\hline 1849 & $\begin{array}{l}\text { Los archivos del Estado quedan adscritos al Ministerio de Gracia y } \\
\text { Justicia }\end{array}$ \\
\hline 1849 & $\begin{array}{l}\text { Real Decreto estableciendo el reglamento de la Dirección General } \\
\text { de Archivos del Ministerio de Gracia y Justicia }\end{array}$ \\
\hline 1850 & $\begin{array}{l}\text { Juan Bravo Murillo ordena el traslado de los fondos documentales } \\
\text { procedentes de los conventos clausurados a la Academia de la His- } \\
\text { toria, origen del Archivo Histórico Nacional }\end{array}$ \\
\hline 1850 & $\begin{array}{l}\text { Por jubilación de Próspero Bofarull, es nombrado Director del Archi- } \\
\text { vo de la Corona de Aragón Manuel de Bofarull }\end{array}$ \\
\hline 1851 & $\begin{array}{l}\text { El Archivo del Consell de Mallorca pasa a ser el Archivo Histórico de } \\
\text { Baleares }\end{array}$ \\
\hline 1851 & $\begin{array}{l}\text { Real Decreto suprimiendo las Juntas Subalternas de Archivos de } \\
\text { provincias }\end{array}$ \\
\hline 1853 & $\begin{array}{l}\text { Real Orden estableciendo que en cada provincia se creará una Co- } \\
\text { misión encargada de la puesta en marcha de un archivo provincial } \\
\text { de Hacienda }\end{array}$ \\
\hline 1853 & $\begin{array}{l}\text { Real Orden estableciendo el reglamento de los archivos de las Au- } \\
\text { diencias Provinciales }\end{array}$ \\
\hline 1853 & $\begin{array}{l}\text { José Castro y Orozco, Ministro de Gracia y Justicia, publica Ins- } \\
\text { trucción del procedimiento civil con respecto a la real jurisdicción or- } \\
\text { dinaria, primera regulación general del derecho procesal realizada } \\
\text { por los liberales }\end{array}$ \\
\hline
\end{tabular}




\begin{tabular}{|c|c|}
\hline Año & Noticia \\
\hline 1853 & $\begin{array}{l}\text { Real Decreto de organización de la planta del Archivo General de In- } \\
\text { dias }\end{array}$ \\
\hline 1853 & $\begin{array}{l}\text { Inauguración de la nueva sede del Archivo de la Corona de Aragón } \\
\text { en el Palacio de los Virreyes en Barcelona }\end{array}$ \\
\hline 1853 & $\begin{array}{l}\text { Es inaugurada la nueva sede del Archivo de la Corona de Aragón en } \\
\text { el antiguo Palacio Real de Barcelona }\end{array}$ \\
\hline 1854 & Apertura del Archivo Central de Alcalá de Henares \\
\hline 1854 & $\begin{array}{l}\text { Real Orden estableciendo el reglamento de los archivos provinciales } \\
\text { de Hacienda }\end{array}$ \\
\hline 1854 & $\begin{array}{l}\text { Real Decreto fijando las normas para el expurgo y la clasificación de } \\
\text { los archivos de las Audiencias }\end{array}$ \\
\hline 1856 & $\begin{array}{l}\text { Creación, por iniciativa de la Real Academia de la Historia, de la Es- } \\
\text { cuela Superior de Diplomática, destinada a formar archiveros }\end{array}$ \\
\hline 1856 & $\begin{array}{l}\text { Real Orden previniendo que los clérigos que se resistan a entregar } \\
\text { sus archivos a las autoridades civiles pagarán el coste que ello pro- } \\
\text { voque }\end{array}$ \\
\hline 1857 & $\begin{array}{l}\text { Real Orden fijando el procedimiento a seguir para la contratación de } \\
\text { archiveros y bibliotecarios }\end{array}$ \\
\hline 1857 & $\begin{array}{l}\text { Se subastan al peso documentos procedentes del expurgo del Ar- } \\
\text { chivo del Ministerio de Hacienda }\end{array}$ \\
\hline 1857 & $\begin{array}{l}\text { José Gonzalo de las Casas publica en Madrid Anales de la Paleo- } \\
\text { grafía española }\end{array}$ \\
\hline 1858 & $\begin{array}{l}\text { Ley de Instrucción Pública de Claudio Moyano, que en su Título II, } \\
\text { Sección } 2 .^{\text {a }} \text { establece que la red de archivos históricos dependerán } \\
\text { del Ministerio de Fomento e Instrucción Pública y crea el Cuerpo Fa- } \\
\text { cultativo de Archiveros y Bibliotecarios }\end{array}$ \\
\hline 1858 & $\begin{array}{l}\text { Modesto Lafuente y Zamalloa, nombrado Presidente de la Junta } \\
\text { Superior Directiva de Archivos y Bibliotecas }\end{array}$ \\
\hline 1859 & $\begin{array}{l}\text { Real Decreto sobre la apertura y organización de los archivos y las } \\
\text { bibliotecas públicas }\end{array}$ \\
\hline 1859 & $\begin{array}{l}\text { Real Orden estableciendo el reglamento del cuerpo de archiveros y } \\
\text { bibliotecarios }\end{array}$ \\
\hline 1859 & $\begin{array}{l}\text { Real Decreto organizando el sistema archivístico público: Habrá } 3 \\
\text { clases de archivos (generales, provinciales y municipales); se crea el } \\
\text { Archivo General Central Histórico para los documentos de los anti- }\end{array}$ \\
\hline
\end{tabular}




\begin{tabular}{|c|c|}
\hline Año & Noticia \\
\hline & $\begin{array}{l}\text { guos Consejos y Secretarías del Antiguo Régimen; se reordena el } \\
\text { Cuerpo Facultativo de Archiveros-bibliotecarios (dividido en tres cla- } \\
\text { ses: archiveros-bibliotecarios, oficiales y ayudantes); creación de la } \\
\text { Junta Suprema de Archivos y Bibliotecas, presidida por Modesto } \\
\text { Lafuente }\end{array}$ \\
\hline 1860 & $\begin{array}{l}\text { La Junta Superior Directiva de Archivos publica unas Instrucciones y } \\
\text { bases para el arreglo y clasificación de los archivos, en las que se } \\
\text { ordena que en la clasificación de los fondos se respete el orden de } \\
\text { procedencia, pero que nunca tendrán carácter normativo }\end{array}$ \\
\hline 1860 & $\begin{array}{l}\text { Real Decreto por el que se fusionan los cargos de Director de la Bi- } \\
\text { blioteca Nacional y Presidente de la Junta Superior Directiva de Ar- } \\
\text { chivos y Bibliotecas }\end{array}$ \\
\hline 1860 & Obras de ampliación en el Archivo del Ministerio de Hacienda \\
\hline 1862 & $\begin{array}{l}\text { La Ley del Notariado dispone que los protocolos con más de } 25 \\
\text { años de antigüedad sean enviados a las sedes de la Audiencias Pro- } \\
\text { vinciales y con ellos se cree un archivo en cada una de ellas }\end{array}$ \\
\hline 1862 & $\begin{array}{l}\text { Se subastan al peso documentos procedentes del expurgo del Ar- } \\
\text { chivo del Ministerio de Hacienda }\end{array}$ \\
\hline 1862 & $\begin{array}{l}\text { Real Orden por el que se establecen las aportaciones económicas } \\
\text { que habrán de hacer las Diputaciones Provinciales para el sosteni- } \\
\text { miento de los archivos y bibliotecas. En total serán } 76.582 \text { pesetas al } \\
\text { año entre todas ellas }\end{array}$ \\
\hline 1863 & $\begin{array}{l}\text { Real Orden ordenando que los registros de las prisiones con más de } \\
\text { seis años de antigüedad sean remitidos a los archivos de las Au- } \\
\text { diencias Provinciales }\end{array}$ \\
\hline 1863 & $\begin{array}{l}\text { Real Orden estableciendo el reglamento de los archivos de las Di- } \\
\text { putaciones Provinciales }\end{array}$ \\
\hline 1864 & $\begin{array}{l}\text { Antonio Bofarull publica en Valencia "Cuestión de archivos, o sea } \\
\text { polémica sobre la mayor o menor propiedad del título que respecti- } \\
\text { vamente llevan los dos archivos generales e históricos de Barcelona } \\
\text { y Valencia» }\end{array}$ \\
\hline 1865 & $\begin{array}{l}\text { Real Orden estableciendo el reglamento de los archivos de las Di- } \\
\text { recciones Generales del Ejército }\end{array}$ \\
\hline 1866 & $\begin{array}{l}\text { Fundación del Archivo Histórico Nacional con fondos procedentes de } \\
\text { los conventos clausurados, aunque carece de sede propia, perma- } \\
\text { neciendo dentro de las instalaciones de la Real Academia de la } \\
\text { Historia. Su primer Director será D. Tomás Muñoz y Romero, que ya }\end{array}$ \\
\hline
\end{tabular}




\begin{tabular}{|c|c|}
\hline Año & Noticia \\
\hline & $\begin{array}{l}\text { era el encargado del Archivo de la Real Academia de la Historia. } \\
\text { Ocupará el cargo hasta } 1867 .\end{array}$ \\
\hline 1866 & $\begin{array}{l}\text { Se subastan al peso documentos procedentes del expurgo del Ar- } \\
\text { chivo del Tribunal de Cuentas ( } 1.300 \text { arrobas) }\end{array}$ \\
\hline 1866 & $\begin{array}{l}\text { Se subastan al peso documentos procedentes del expurgo del Ar- } \\
\text { chivo de la Dirección General de Rentas Estancas y Loterías }\end{array}$ \\
\hline 1867 & $\begin{array}{l}\text { Juan de Tro y Ortolano, licenciado en Derecho y catedrático de la } \\
\text { Escuela Superior de Diplomática, es nombrado Director del Archivo } \\
\text { Histórico Nacional. Sería cesado por el gobierno revolucionario en } \\
\text { 1868, volviendo a ser designado tras la Restauración borbónica en } \\
\text { 1874, ocupando entonces el cargo hasta } 1875 .\end{array}$ \\
\hline 1867 & $\begin{array}{l}\text { Decreto sobre la organización de los archivos estatales: Dependerán } \\
\text { de la Dirección General de Instrucción Pública; se dividirán en dos } \\
\text { clases, de } 1 .^{\text {a }} \text { (Simancas, Central de Alcalá, Histórico Nacional y } \\
\text { Corona de Aragón) y } 2 .^{a} \text { (Valencia, Galicia y Mallorca); las entidades } \\
\text { administrativas remitirán a los archivos los documentos de más de } \\
30 \text { años; la Escuela Superior de Diplomática se encargará de la } \\
\text { formación de los archiveros; y se reorganiza el Cuerpo Facultativo de } \\
\text { Archiveros y Bibliotecarios }\end{array}$ \\
\hline 1867 & $\begin{array}{l}\text { Los «anticuarios» o museólogos se adscriben al Cuerpo Facultativo } \\
\text { de Archiveros y Bibliotecarios }\end{array}$ \\
\hline 1868 & $\begin{array}{l}\text { El Ministro de Instrucción Pública, Ruiz Zorrilla, llegado al cargo } \\
\text { tras la Gloriosa Revolución, cesa al Director del Archivo Histórico Na- } \\
\text { cional y nombra para el cargo a José Sanz Pérez, literato y perio- } \\
\text { dista. }\end{array}$ \\
\hline 1869 & $\begin{array}{l}\text { Manuel Ruiz Zorrilla, Ministro de Fomento, decreta la incautación de } \\
\text { todos los archivos, bibliotecas y objetos de arte que permanezcan en } \\
\text { manos del clero }\end{array}$ \\
\hline 1869 & $\begin{array}{l}\text { Decreto ordenando la apertura de un Archivo General de Protocolos } \\
\text { en cada Distrito Notarial. Le serán remitidos los protocolos de más } \\
\text { de } 30 \text { años, estarán ubicados en la sede del Juzgado de Primera } \\
\text { Instancia del Distrito y lo gestionará, bajo la supervisión del Juez, un } \\
\text { Notario-archivero }\end{array}$ \\
\hline 1870 & $\begin{array}{l}\text { Luis de Eguilaz y Eguilaz, dramaturgo, es designado Director del Ar- } \\
\text { chivo Histórico Nacional, cargo que ocupará hasta } 1874 \text {, cuando } \\
\text { se produce la Restauración borbónica }\end{array}$ \\
\hline
\end{tabular}




\begin{tabular}{|c|c|}
\hline Año & Noticia \\
\hline 1870 & $\begin{array}{l}\text { Real Orden Comunicada ordenando que, a petición del Director Ge- } \\
\text { neral de Instrucción Pública, se aumente el número de funcionarios } \\
\text { del cuerpo facultativo de archivos y museos, por ser la actual planti- } \\
\text { lla insuficiente para inventariar los fondos puestos a su cargo }\end{array}$ \\
\hline 1871 & $\begin{array}{l}\text { Comienza a editarse la Revista de Archivos, Bibliotecas y Museos en } \\
\text { Madrid, que se editará hasta 1986, aunque con algunos paréntesis } \\
\text { en los que no se publicó: } 1879-1895 ; 1931-1946 \text { y 1968-1971 }\end{array}$ \\
\hline 1871 & $\begin{array}{l}\text { Decreto reformando la planta del Archivo del Ministerio de Gracia y } \\
\text { Justicia }\end{array}$ \\
\hline 1871 & $\begin{array}{l}\text { José María Escudero de la Peña publica en la Revista de Archivos, } \\
\text { Bibliotecas y Museos un artículo titulado «El Archivo General Central } \\
\text { de Alcalá de Henares en peligro (necesidad inmediata de reparación } \\
\text { del edificio)» }\end{array}$ \\
\hline 1871 & $\begin{array}{l}\text { José María Escudero de la Peña publica en la Revista de Archivos, } \\
\text { Bibliotecas y Museos un artículo titulado "Archivo General de Si- } \\
\text { mancas: conveniencia de su traslado a Valladolid» }\end{array}$ \\
\hline 1871 & $\begin{array}{l}\text { José María Escudero de la Peña publica en la Revista de Archivos, } \\
\text { Bibliotecas y Museos un artículo titulado "Observaciones sobre la } \\
\text { clasificación de los archivos" }\end{array}$ \\
\hline 1871 & $\begin{array}{l}\text { Toribio Campillo y Casamor publica en la Revista de Archivos, Bi- } \\
\text { bliotecas y Museos un artículo titulado «El Archivo de la Comunidad } \\
\text { de Daroca. Noticias del abandono en que se halla su rica docu- } \\
\text { mentación e ingreso en el Archivo Histórico Nacional» (en } 1876 \\
\text { será trasladado al A.H.N.) }\end{array}$ \\
\hline 1871 & $\begin{array}{l}\text { Se designa a un archivero-bibliotecario para el Ministerio de la Go- } \\
\text { bernación }\end{array}$ \\
\hline 1871 & $\begin{array}{l}\text { Decreto estableciendo el Reglamento de los archivos, bibliotecas y } \\
\text { museos públicos }\end{array}$ \\
\hline 1871 & $\begin{array}{l}\text { Se hace público un proyecto para crear el Cuerpo de Aspirantes al } \\
\text { Cuerpo Facultativo de Archiveros, Bibliotecarios y Anticuarios }\end{array}$ \\
\hline 1872 & $\begin{array}{l}\text { Creación del Servicio Nacional del Tesoro Documental y Bibliográ- } \\
\text { fico, al que se le encomendará la elaboración de un «inventario ge- } \\
\text { neral» de los fondos archivísticos y bibliográficos de la nación }\end{array}$ \\
\hline 1872 & $\begin{array}{l}\text { Miguel Velasco y Santos publica en la Revista de Archivos, Biblio- } \\
\text { tecas y Museos un artículo titulado «Necesidades urgentes del Ar- } \\
\text { chivo General de Valencia» }\end{array}$ \\
\hline
\end{tabular}




\begin{tabular}{|c|c|}
\hline Año & Noticia \\
\hline 1872 & $\begin{array}{l}\text { Los fondos del Conventual de Uclés (Orden de Santiago) son trans- } \\
\text { feridos al Archivo Histórico Nacional y al Provincial de Cuenca }\end{array}$ \\
\hline 1873 & $\begin{array}{l}\text { Decreto suprimiendo el Cuerpo Colegiado de Caballeros Hijosdalgo } \\
\text { de Madrid, cuyo archivo será incautado y remitido al municipal de } \\
\text { Madrid (en } 1875 \text { la organización será restituida y su archivo devuel- } \\
\text { to) }\end{array}$ \\
\hline 1873 & $\begin{array}{l}\text { Se publica en la Revista de Archivos, Bibliotecas y Museos un artí- } \\
\text { culo sobre el descubrimiento en Boston (EE.UU.) de una tecnología } \\
\text { que permite leer los documentos quemados }\end{array}$ \\
\hline 1873 & $\begin{array}{l}\text { Los fondos de los Patronatos Reales son transferidos al Archivo } \\
\text { del Ministerio de la Gobernación }\end{array}$ \\
\hline 1873 & $\begin{array}{l}\text { Francisco Romero de Castilla publica en la Revista de Archivos, } \\
\text { Bibliotecas y Museos un artículo titulado «Apuntes históricos sobre } \\
\text { el Archivo de la Corona de Castilla situado en la villa de Simancas» }\end{array}$ \\
\hline 1873 & $\begin{array}{l}\text { Se procesa a los responsables municipales de Burguillos por vender } \\
\text { la documentación del archivo municipal }\end{array}$ \\
\hline 1873 & $\begin{array}{l}\text { Circular ordenando a los Gobernadores que inspeccionen el estado } \\
\text { de los archivos municipales de su provincia }\end{array}$ \\
\hline 1873 & $\begin{array}{l}\text { Real Orden por la que se establece que los Institutos de Enseñanzas } \\
\text { Medias se harán cargo de los archivos de todos los centros educa- } \\
\text { tivos de su provincia }\end{array}$ \\
\hline 1874 & $\begin{array}{l}\text { Patricio Ferrer y Ruiz Delgado publica en la Revista de Archivos, Bi- } \\
\text { bliotecas y Museos un artículo titulado «Historia de Simancas. Cas- } \\
\text { tillo y archivo» }\end{array}$ \\
\hline 1874 & $\begin{array}{l}\text { José Güemes publica en la Revista de Archivos, Bibliotecas y Mu- } \\
\text { seos un artículo titulado "Diferentes clases de papel de que se } \\
\text { hace uso en las escrituras en los diferentes pueblos del mundo" }\end{array}$ \\
\hline 1875 & $\begin{array}{l}\text { Francisco González de Vera, bibliógrafo y antiguo Director del Ar- } \\
\text { chivo General Central de Alcalá de Henares, es nombrado Director } \\
\text { del Archivo Histórico Nacional, cargo que ocupará hasta } 1896\end{array}$ \\
\hline 1875 & $\begin{array}{l}\text { Miguel Velasco y Santos, Director del Archivo General Central de Al- } \\
\text { calá de Henares, publica «Sobre la organización de archivos» en la } \\
\text { Revista de Archivos, Bibliotecas y Museos }\end{array}$ \\
\hline 1875 & $\begin{array}{l}\text { Real Decreto ordenando la devolución al clero de los archivos que le } \\
\text { habían sido incautados por el Real Decreto de } 1 \text { de enero de } 1869\end{array}$ \\
\hline
\end{tabular}




\begin{tabular}{|c|c|}
\hline Año & Noticia \\
\hline 1875 & $\begin{array}{l}\text { Real Decreto disolviendo la Junta Superior Directiva de Archivos y } \\
\text { Bibliotecas y creación de la Junta Facultativa de Bibliotecas, Archi- } \\
\text { vos y Museos de Antigüedades }\end{array}$ \\
\hline 1876 & $\begin{array}{l}\text { José Güemes Willame, Archivero General de la Real Casa, publica } \\
\text { en Madrid Organización del archivo de la Corona aplicada a los ar- } \\
\text { chivos particulares }\end{array}$ \\
\hline 1876 & $\begin{array}{l}\text { Real Decreto ordenando que los archivos de las Escribanías de } \\
\text { Marina serán remitidos a los Archivos Generales de Protocolos de } \\
\text { sus distritos judiciales, conforme éstas vayan vacando }\end{array}$ \\
\hline 1876 & $\begin{array}{l}\text { Los fondos de los antiguos Consejos de Castilla y Hacienda, más los } \\
\text { de la Cámara de Castilla ( } 15.000 \text { legajos) son transferidos al Archivo } \\
\text { General Central de Alcalá de Henares }\end{array}$ \\
\hline 1876 & $\begin{array}{l}\text { Se envían al Archivo Histórico Nacional una colección de sellos pro- } \\
\text { cedentes de las diversas dependencias del Estado }\end{array}$ \\
\hline 1876 & $\begin{array}{l}\text { El Archivo Universitario de Salamanca pasa a ser servido por el } \\
\text { Cuerpo Facultativo de Archiveros }\end{array}$ \\
\hline 1876 & $\begin{array}{l}\text { El Archivo Universitario de Madrid será servido por el Cuerpo Fa- } \\
\text { cultativo de Archiveros }\end{array}$ \\
\hline 1877 & $\begin{array}{l}\text { Luis Rodríguez de Miguel, archivero de la Diputación de Toledo, } \\
\text { publica en Madrid Manual del archivero o sea teoría práctica del ar- } \\
\text { rreglo y clasificación de los archivos }\end{array}$ \\
\hline 1877 & $\begin{array}{l}\text { Toribio Campillo y Casamor, en nombre de los funcionarios del Ar- } \\
\text { chivo de Simancas, eleva un informe al Ministro de Fomento titulado } \\
\text { «Exposición encareciendo la necesidad del traslado del archivo» }\end{array}$ \\
\hline 1877 & $\begin{array}{l}\text { José Güemes Willame publica en la Revista de Archivos, Bibliotecas } \\
\text { y Museos un artículo titulado «Memoria sobre la organización del Ar- } \\
\text { chivo de la Corona» }\end{array}$ \\
\hline 1878 & $\begin{array}{l}\text { Se rehabilita la Casa de los Canónigos de Madrid como archivo del } \\
\text { Tribunal Supremo }\end{array}$ \\
\hline 1878 & $\begin{array}{l}\text { Circular sobre la organización de los archivos provinciales de Ha- } \\
\text { cienda }\end{array}$ \\
\hline 1878 & Alfonso XII visita el Archivo de Simancas \\
\hline 1879 & $\begin{array}{l}\text { José Morón y Limiana publica en Valencia Metodología diplomática } \\
\text { o manual de Arquivomanía }\end{array}$ \\
\hline
\end{tabular}




\begin{tabular}{|c|c|}
\hline Año & Noticia \\
\hline 1880 & $\begin{array}{l}\text { El Cuerpo Facultativo de Archivos y Bibliotecas edita el Boletín His- }- \text { é } \\
\text { tórico, dedicado a la publicación de artículos de historia. Se editará } \\
\text { hasta } 1888,12 \text { números en total. Su edición sustituye durante algu- } \\
\text { nos años a la Revista de Archivos, Bibliotecas y Museos, que había } \\
\text { dejado de editarse en } 1879\end{array}$ \\
\hline 1881 & $\begin{array}{l}\text { Apertura a los investigadores del Archivo Vaticano, ejemplo que } \\
\text { será seguido por múltiples archivos de la Iglesia }\end{array}$ \\
\hline 1881 & $\begin{array}{l}\text { Comienza a editarse el Anuario del Cuerpo Facultativo de Archivos, } \\
\text { Bibliotecas y Museos, con la intención de permitir la publicación de } \\
\text { artículos completos. Sólo se editarán dos números, hasta } 1882\end{array}$ \\
\hline 1881 & Creación del Archivo Histórico de Toledo, suprimido en 1896 \\
\hline 1882 & $\begin{array}{l}\text { Según las estadísticas del Cuerpo Facultativo de Archiveros, Bi- } \\
\text { bliotecarios y Anticuarios que publica la Revista de Archivos, Biblio- } \\
\text { tecas y Museos, el Cuerpo está formado por } 176 \text { funcionarios: } 16 \text { je- } \\
\text { fes de primera, segunda y tercera clase; } 47 \text { oficiales de primera, } \\
\text { segunda y tercera clase; y } 113 \text { ayudantes de primera, segunda y ter- } \\
\text { cera clase }\end{array}$ \\
\hline 1882 & $\begin{array}{l}\text { Según las estadísticas del Cuerpo Facultativo de Archiveros, Bi- } \\
\text { bliotecarios y Anticuarios que publica la Revista de Archivos, Biblio- } \\
\text { tecas y Museos, los archivos servidos por el Cuerpo son: Archivo } \\
\text { Histórico Nacional, General Central de Alcalá, General de Simancas, } \\
\text { Corona de Aragón, Reino de Valencia, Reino de Galicia en La Co- } \\
\text { ruña, Palma de Mallorca, Histórico de Toledo, Universitario de Ma- } \\
\text { drid, Universitario de Barcelona y Universitario de Salamanca }\end{array}$ \\
\hline 1883 & $\begin{array}{l}\text { Juan Antonio Morlesín y Soto publica en la Revista de Archivos, } \\
\text { Bibliotecas y Museos un artículo titulado «Necesidad y conveniencia } \\
\text { de la incorporación de los archivos y bibliotecas que dependen del } \\
\text { Estado al Cuerpo Facultativo de Archiveros, Bibliotecarios y Anti- } \\
\text { cuarios» }\end{array}$ \\
\hline 1883 & $\begin{array}{l}\text { José Muñoz y Rivero escribe un informe al Ministro de Fomento ti- } \\
\text { tulado «Archivo de Simancas. Conveniencia de su traslación a la ca- } \\
\text { pital de Castilla y necesidad de inmediata inspección y arreglo del } \\
\text { Archivo Municipal de Valladolid» }\end{array}$ \\
\hline 1883 & $\begin{array}{l}\text { El Archivo General de Indias pasa a ser servido por el Cuerpo Fa- } \\
\text { cultativo de Archiveros }\end{array}$ \\
\hline 1883 & $\begin{array}{l}\text { Orden estableciendo un Reglamento para las asociaciones de ar- } \\
\text { chiveros, bibliotecarios y anticuarios }\end{array}$ \\
\hline
\end{tabular}




\begin{tabular}{|c|c|}
\hline Año & Noticia \\
\hline 1883 & Se funda la "Sociedad de Archiveros, Bibliotecarios y Anticuarios» \\
\hline 1883 & Se liberaliza por completo la edición de periódicos en España \\
\hline 1884 & $\begin{array}{l}\text { José Muñoz y Rivero, primer catedrático de Paleografía en España, } \\
\text { publica en Madrid Paleografía diplomática española de los siglos XII } \\
\text { al XVII }\end{array}$ \\
\hline 1884 & $\begin{array}{l}\text { Un Real Decreto regula la forma de acceso al Cuerpo Facultativo de } \\
\text { Archivos y Bibliotecas, exigiéndose ser titulados universitarios o } \\
\text { bien por la Escuela Superior de Diplomática }\end{array}$ \\
\hline 1884 & $\begin{array}{l}\text { El Ministerio de Gracia y Justicia dispone la fundación de un Archivo } \\
\text { Central de Protocolos }\end{array}$ \\
\hline 1884 & $\begin{array}{l}\text { Decreto aprobando el proyecto de un Edificio incombustible en el ba- } \\
\text { rrio madrileño del Buen Retiro para albergar el Archivo Central de } \\
\text { Protocolos del Ministerio de Gracia y Justicia, con un presupuesto de } \\
374.450 \text { pesetas }\end{array}$ \\
\hline 1885 & Creación del Archivo del Ministerio de Marina \\
\hline 1887 & $\begin{array}{l}\text { Un Real Decreto establece que el acceso al Cuerpo de Archivos y } \\
\text { Bibliotecas será por oposición }\end{array}$ \\
\hline 1888 & $\begin{array}{l}\text { El Ministerio de Hacienda crea la primera red de archivos provincia- } \\
\text { les }\end{array}$ \\
\hline 1888 & $\begin{array}{l}\text { Real Decreto estableciendo que los funcionarios del cuerpo faculta- } \\
\text { tivo de Archivos y Museos supervisarán la reorganización de los } \\
\text { archivos provinciales del Ministerio de Hacienda }\end{array}$ \\
\hline 1889 & $\begin{array}{l}\text { Real Decreto estableciendo el reglamento de los archivos provin- } \\
\text { ciales de Hacienda }\end{array}$ \\
\hline 1893 & $\begin{array}{l}\text { Real Orden ordenando la elaboración de un catálogo general de } \\
\text { los documentos existentes en archivos, museos y bibliotecas del } \\
\text { Estado }\end{array}$ \\
\hline 1893 & $\begin{array}{l}\text { Se subastan al peso documentos procedentes del expurgo del Ar- } \\
\text { chivo del Ministerio de Hacienda }\end{array}$ \\
\hline 1893 & $\begin{array}{l}\text { El Cuerpo Facultativo de Archiveros se hace cargo del Archivo del } \\
\text { Ministerio de Hacienda }\end{array}$ \\
\hline 1894 & Real Decreto por el que se crea el Archivo Central de Hacienda \\
\hline 1894 & $\begin{array}{l}\text { Mediante Real Orden, el Archivo General de Indias pasa a depender } \\
\text { del Cuerpo Facultativo de Archiveros }\end{array}$ \\
\hline
\end{tabular}




\begin{tabular}{|c|c|}
\hline Año & Noticia \\
\hline 1894 & $\begin{array}{l}\text { El Archivo del Ministerio de la Gobernación pasa a ser servido por el } \\
\text { Cuerpo Facultativo de Archiveros }\end{array}$ \\
\hline 1894 & $\begin{array}{l}\text { Las plazas disponibles en los archivos de las diputaciones y muni- } \\
\text { cipales serán cubiertas por miembros del Cuerpo Facultativo de Ar- } \\
\text { chiveros }\end{array}$ \\
\hline 1895 & $\begin{array}{l}\text { Se subastan al peso documentos procedentes del expurgo del Ar- } \\
\text { chivo del Ministerio de Hacienda }\end{array}$ \\
\hline 1895 & $\begin{array}{l}\text { Manuel Fernández Mourillo publica en Madrid Apuntes de Sigilo- } \\
\text { grafía española o estudio de los sellos }\end{array}$ \\
\hline 1896 & $\begin{array}{l}\text { Vicente Vignau y Ballester, teólogo, licenciado en Derecho, diplo- } \\
\text { mado en la Escuela Superior de Diplomática y miembro del Cuerpo } \\
\text { Facultativo de Archiveros, es designado Director del Archivo Histó- } \\
\text { rico Nacional, puesto que ocupará hasta } 1908\end{array}$ \\
\hline 1896 & $\begin{array}{l}\text { El Archivo Histórico Nacional se traslada desde la Academia de la } \\
\text { Historia al edificio de la Biblioteca Nacional }\end{array}$ \\
\hline 1896 & $\begin{array}{l}\text { Manuel Fernández Mourillo publica en la Revista de Archivos, Bi- } \\
\text { bliotecas y Museos un artículo titulado "Archivo Histórico Nacional. } \\
\text { Conveniencia de reunir en este archivo todos los papeles de valor } \\
\text { histórico que hoy se hallan en Simancas y Alcalá» }\end{array}$ \\
\hline 1896 & $\begin{array}{l}\text { Comienza a editarse el Boletín de Archivos, Bibliotecas y Museos, } \\
\text { como órgano oficial del Montepío del Cuerpo. Se editarán ocho nú- } \\
\text { meros, todos en } 1896\end{array}$ \\
\hline 1896 & Se dota de teléfono al Archivo General de Simancas \\
\hline 1896 & $\begin{array}{l}\text { Ingresan en el Archivo Histórico Nacional los fondos del suprimido } \\
\text { Archivo Histórico de Toledo }\end{array}$ \\
\hline 1897 & Las Órdenes Militares donan su archivo histórico al Estado \\
\hline 1897 & $\begin{array}{l}\text { Los fondos de los antiguos Consejos, más los de la Cámara de } \\
\text { Castilla (15.000 legajos) son transferidos desde el Archivo General } \\
\text { Central de Alcalá de Henares al Archivo Histórico Nacional }\end{array}$ \\
\hline 1897 & $\begin{array}{l}\text { El Consejo Real transfiere los archivos de la Escribanía de Gobierno, } \\
\text { el Archivo Antiguo o Reservado del Consejo de Castilla y la Secre- } \\
\text { taría de Presidencia del Consejo de Castilla al Archivo Histórico } \\
\text { Nacional }\end{array}$ \\
\hline 1897 & $\begin{array}{l}\text { El Ministerio de Gracia y Justicia transfiere los fondos del Registro } \\
\text { General del Sello al Archivo Histórico Nacional }\end{array}$ \\
\hline
\end{tabular}




\begin{tabular}{c|l} 
Año & Noticia \\
\hline 1897 & $\begin{array}{l}\text { Francisco Navarro y Ledesma publica en la Revista de Archivos, Bi- } \\
\text { bliotecas y Museos un artículo titulado «Necesidad de una Ley de } \\
\text { Antigüedades» }\end{array}$ \\
\hline 1897 & $\begin{array}{l}\text { Ingresan en el Archivo Histórico Nacional los fondos de la extinta } \\
\text { Universidad de Sigüenza }\end{array}$ \\
\hline 1898 & Se crea el Archivo General Militar de Segovia en el Alcázar \\
\hline 1898 & Traslado del Archivo General de Navarra a su actual sede \\
\hline 1898 & $\begin{array}{l}\text { Se subastan al peso documentos procedentes del expurgo del Ar- } \\
\text { chivo del Ministerio de Hacienda }\end{array}$ \\
\hline 1899 & $\begin{array}{l}\text { Se subastan al peso documentos procedentes del expurgo del Ar- } \\
\text { chivo del Ministerio de Hacienda }\end{array}$ \\
\hline 1899 & $\begin{array}{l}\text { Los fondos de las Escribanías de Cámara del Consejo de Castilla y } \\
\text { del Consejo de Hacienda son transferidos desde el Tribunal Supre- } \\
\text { mo al Archivo Histórico Nacional (19.525 legajos y 739 libros) }\end{array}$ \\
\hline 1900 & $\begin{array}{l}\text { Marcelino Gutiérrez del Caña publica en la Revista de Archivos, Bi- } \\
\text { bliotecas y Museos un artículo titulado «Ensayo de un catálogo de } \\
\text { impresores españoles desde la introducción de la imprenta hasta el } \\
\text { siglo XVIIl» }\end{array}$ \\
\hline 1899 & $\begin{array}{l}\text { Son transferidos al Archivo Histórico Nacional los fondos del Minis- } \\
\text { terio de Estado anteriores a 1801 }\end{array}$ \\
\hline 1899 & $\begin{array}{l}\text { Ingresan en el Archivo Histórico Nacional 150 toneladas de docu- } \\
\text { per el Cuerpo Facultativo de Archiveros } \\
\text { to Rico }\end{array}$ \\
\hline 1900 & $\begin{array}{l}\text { Se clausura la Escuela Superior de Diplomática } \\
\text { Real Decreto estableciendo las normas reguladoras del acceso a los } \\
\text { documentos y para la obtención de copias en los archivos. Para } \\
\text { consultar documentos relacionados con la diplomacia española pos- } \\
\text { teriores a 1700 será necesaria una autorización especial del Ministro }\end{array}$ \\
\hline $\begin{array}{l}\text { Real Decreto sobre «Defensa servido } \\
\text { oficial del Cuerpo Facultativo de Archiveros y se obliga a todos los } \\
\text { centros dependientes del Cuerpo a suscribirse a ella }\end{array}$ \\
\hline 1900
\end{tabular}




\begin{tabular}{|c|c|}
\hline Año & Noticia \\
\hline 1900 & $\begin{array}{l}\text { Decreto estableciendo las normas para la copia de documentos en } \\
\text { los archivos del Estado }\end{array}$ \\
\hline 1900 & $\begin{array}{l}\text { Real Decreto reformando el Reglamento del Cuerpo de Archiveros, } \\
\text { Bibliotecarios y Anticuarios }\end{array}$ \\
\hline 1901 & $\begin{array}{l}\text { Real Decreto estableciendo el Reglamento de los Archivos del Es- } \\
\text { tado. Se reorganiza el Cuerpo Facultativo de Archiveros, sustitu- } \\
\text { yéndose el término «anticuarios» por el de «arqueólogos». El Di- } \\
\text { rector del Cuerpo será el de la Biblioteca Nacional; el de la Sección } \\
\text { de Archiveros, el Director del Archivo Histórico Nacional; el de la } \\
\text { Sección de Arqueólogos, el del Museo Arqueológico Nacional; y e } \\
\text { de la Sección de Bibliotecarios, el facultativo más antiguo de la Bi- } \\
\text { blioteca Nacional. Se crea la Inspección General de Archivos, desti- } \\
\text { nada a visitar periódicamente los centros servidos por el Cuerpo } \\
\text { Facultativo de Archiveros }\end{array}$ \\
\hline 1902 & $\begin{array}{l}\text { Ante la constatación de que los notarios incumplen la Ley sobre ar- } \\
\text { chivos del notariado de } 1869 \text { y no envían los protocolos a los archi- } \\
\text { vos, un Real Decreto establece multas para quienes no lo hagan }\end{array}$ \\
\hline 1902 & $\begin{array}{l}\text { Se crean cátedras de Paleografía en las universidades de Zaragoza, } \\
\text { Barcelona, Granada, Salamanca y Sevilla }\end{array}$ \\
\hline 1903 & $\begin{array}{l}\text { Donación al Estado del Archivo Histórico de la Orden de San Juan } \\
\text { de Jerusalén }\end{array}$ \\
\hline 1903 & Alfonso XIII visita el Archivo General de Simancas \\
\hline 1904 & $\begin{array}{l}\text { Real Orden por la que se incorporan a la red de centros servidos por } \\
\text { el Cuerpo Facultativo de Archivos y Bibliotecas los archivos de las } \\
\text { Chancillerías de Valladolid y de Granada }\end{array}$ \\
\hline 1904 & $\begin{array}{l}\text { Real Orden transfiriendo al Archivo Histórico Nacional los fondos ar- } \\
\text { chivísticos del suprimido Ministerio de Ultramar y los procedentes de } \\
\text { las colonias }\end{array}$ \\
\hline 1904 & $\begin{array}{l}\text { Real Orden por la que se dota de calefacción al Archivo Histórico } \\
\text { Nacional, en su sede del Palacio de la Biblioteca Nacional }\end{array}$ \\
\hline 1906 & $\begin{array}{l}\text { El archivo de la Chancillería se independiza de la Audiencia Provin- } \\
\text { cial de Valladolid }\end{array}$ \\
\hline 1906 & $\begin{array}{l}\text { El archivo de la Chancillería se independiza de la Audiencia Provin- } \\
\text { cial de Granada (hasta } 1958 \text { no tendrá edificio propio) }\end{array}$ \\
\hline 1906 & $\begin{array}{l}\text { Narciso José de Liñán y Heredia, Conde de Doña María, publica en } \\
\text { la Revista de Archivos, Bibliotecas y Museos un artículo titulado } \\
\text { «El archivo de la Casa de Osuna. Medidas para impedir su pérdida» }\end{array}$ \\
\hline
\end{tabular}




\begin{tabular}{c|l} 
Año & Noticia \\
\hline 1906 & $\begin{array}{l}\text { El Sr. Piernas Hurtado publica en la Revista de Archivos, Bibliotecas } \\
\text { y Museos un artículo titulado «Conveniencia de trasladar el Archivo } \\
\text { de Simancas» }\end{array}$ \\
\hline 1906 & $\begin{array}{l}\text { Francisco Álvarez Osorio publica en la Revista de Archivos, Biblio- } \\
\text { tecas y Museos un artículo titulado «Breve noticia del archivo que } \\
\text { fue del Duque de Osuna» }\end{array}$ \\
\hline 1907 & $\begin{array}{l}\text { Francisco Rico y Guisasola publica en la Revista de Archivos, Bi- } \\
\text { bliotecas y Museos un artículo titulado «El Archivo del Ministerio } \\
\text { de Marina. Clasificación de sus fondos» }\end{array}$ \\
\hline 1908 & $\begin{array}{l}\text { Juan Menéndez Pidal, licenciado en Derecho, político y gobernador } \\
\text { civil en varias ocasiones, además de reputado folklorista y miembro } \\
\text { del Cuerpo Facultativo de Archiveros, es nombrado Director del Ar- } \\
\text { chivo Histórico Nacional, puesto que ocupará hasta 1915 }\end{array}$ \\
\hline 1908 & $\begin{array}{l}\text { Alfredo Basanta de la Riva publica en la Revista de Archivos, Bi- } \\
\text { bliotecas y Museos un artículo titulado «Historia y organización del } \\
\text { archivo de la antigua Chancillería de Valladolid» }\end{array}$ \\
\hline 1910 & $\begin{array}{l}\text { La Junta Facultativa del Cuerpo de Archiveros y Bibliotecarios pu- } \\
\text { blica «Instrucciones para la catalogación de manuscritos y estampas } \\
\text { en las bibliotecas públicas» }\end{array}$ \\
\hline 1911 & $\begin{array}{l}\text { José Vila Serra publica en Valencia Manual con la legislación refe- } \\
\text { rente a archivos, bibliotecas y museos }\end{array}$ \\
\hline 1911 & $\begin{array}{l}\text { Se hace público un proyecto para crear un Cuerpo de Auxiliares de } \\
\text { Archivos, Bibliotecas y Museos }\end{array}$ \\
\hline 1911 & $\begin{array}{l}\text { Real Decreto ordenando la jubilación forzosa de los funcionarios } \\
\text { del Cuerpo Facultativo de Archiveros a los 65 años }\end{array}$ \\
\hline $\begin{array}{l}\text { El Archivo General de Simancas publica el Catálogo de la Sección } \\
\text { de Patronato Real (834-1851) }\end{array}$ \\
\hline $\begin{array}{l}\text { Prohibición de consultar en los archivos públicos documentos eco- } \\
\text { nómicos sobre las comunidades religiosas desamortizadas }\end{array}$ \\
\hline $\begin{array}{l}\text { Clemente Calvo Iriarte publica en la Revista de Archivos, Bibliotecas } \\
\text { y Museos un artículo titulado «Los archiveros-bibliotecarios, reformas } \\
\text { necesarias» }\end{array}$ \\
\hline $\begin{array}{l}\text { Se hace público un proyecto de «Reglamento para archivos provin- } \\
\text { ciales y municipales» }\end{array}$ \\
\hline 1913 archiveros a los 67 años
\end{tabular}




\begin{tabular}{|c|c|}
\hline Año & Noticia \\
\hline 1914 & $\begin{array}{l}\text { Real Orden ordenando el intercambio de fondos entre el Archivo His- } \\
\text { tórico Nacional y Simancas, al objeto de completar y unificar las } \\
\text { series: } 4.000 \text { legajos de Simancas sobre la Inquisición serán trasla- } \\
\text { dados al A.H.N. y } 700 \text { legajos sobre Hacienda, el Consejo de Casti- } \\
\text { lla y el Consejo de Indias desde el A.H.N. a Simancas }\end{array}$ \\
\hline 1914 & $\begin{array}{l}\text { Se crea en el Archivo General de Indias el «Centro de Estudios } \\
\text { Americanistas», con un presupuesto anual de } 20.000 \text { pesetas }\end{array}$ \\
\hline 1914 & $\begin{array}{l}\text { Real Orden denegando la solicitud de creación de un Cuerpo de Ar- } \\
\text { chiveros Provinciales y Municipales }\end{array}$ \\
\hline 1915 & $\begin{array}{l}\text { El Archivo de las Órdenes Militares pasa a ser servido por el Cuerpo } \\
\text { Facultativo de Archiveros }\end{array}$ \\
\hline 1916 & $\begin{array}{l}\text { Se publica en Madrid la Guía histórica y descriptiva de los archivos, } \\
\text { bibliotecas y museos arqueológicos de España que están a cargo } \\
\text { del Cuerpo Facultativo del ramo }\end{array}$ \\
\hline 1916 & $\begin{array}{l}\text { Juan González Fernández, Licenciado en Derecho y facultativo del } \\
\text { Cuerpo de Archiveros, es nombrado Director del Archivo Histórico } \\
\text { Nacional, puesto que ocupará hasta } 1930\end{array}$ \\
\hline 1916 & $\begin{array}{l}\text { Amalio Huarte y Echenique publica en Salamanca El Archivo Uni- } \\
\text { versitario de Salamanca }\end{array}$ \\
\hline 1916 & $\begin{array}{l}\text { Ricardo Arco y Garay publica en la Revista de Archivos, Bibliotecas } \\
\text { y Museos un artículo titulado «La cultura, la investigación histórico- } \\
\text { artística y los archivos de protocolos notariales» }\end{array}$ \\
\hline 1916 & $\begin{array}{l}\text { Jesús Ernesto Martínez Ferrando, nombrado Director del Archivo de } \\
\text { la Corona de Aragón }\end{array}$ \\
\hline 1917 & $\begin{array}{l}\text { El Código de Derecho Canónico, dictado por el Papa Benedicto XV, } \\
\text { fija las normas reguladoras de la formación de los archiveros de la } \\
\text { Iglesia, los límites en el acceso de particulares a los archivos ecle- } \\
\text { siásticos y la organización de los archivos }\end{array}$ \\
\hline 1918 & $\begin{array}{l}\text { Juan Menéndez Pidal publica en Madrid el primer catálogo de la sec- } \\
\text { ción de Sigilografía del Archivo Histórico Nacional: Catálogo I: Sellos } \\
\text { españoles de la Edad Media }\end{array}$ \\
\hline 1919 & $\begin{array}{l}\text { Zacarías García Villada publica en Madrid Catálogo de los códices y } \\
\text { documentos de la Catedral de León }\end{array}$ \\
\hline 1920 & $\begin{array}{l}\text { Real Orden por la que se dota una plaza de restaurador, "con co- } \\
\text { nocimientos de galvanoplastia», en el Archivo Histórico Nacional }\end{array}$ \\
\hline
\end{tabular}




\begin{tabular}{|c|c|}
\hline Año & ia \\
\hline $\begin{array}{l}1920- \\
1923\end{array}$ & $\begin{array}{l}\text { Alfredo Basanta publica en Valladolid Archivo de la Chancillería de } \\
\text { Valladolid. Sala de Hijosdalgo. Catálogo de todos sus pleitos, expe- } \\
\text { dientes y probanzas, en } 4 \text { volúmenes }\end{array}$ \\
\hline 1921 & $\begin{array}{l}\text { El Archivo de la Corona de Aragón deja de depender de la Casa } \\
\text { Real para incorporarse a la Dirección General del Real Patrimonio }\end{array}$ \\
\hline 1923 & $\begin{array}{l}\text { Agustín Millares Carlo publica en Madrid Manual de Paleografía es- } \\
\text { pañola }\end{array}$ \\
\hline 1923 & $\begin{array}{l}\text { Zacarías García Villada publica en Madrid Paleografía española, } \\
\text { precedida de una introducción sobre la Paleografía latina }\end{array}$ \\
\hline 1923 & $\begin{array}{l}\text { Pío XI crea en Roma la «Escuela de Paleografía y Diplomática», en } \\
\text { la que se formarán muchos archiveros de la Iglesia española }\end{array}$ \\
\hline 1923 & $\begin{array}{l}\text { Asamblea del Cuerpo Facultativo de Archiveros, Bibliotecarios y Ar- } \\
\text { queólogos. Las ponencias se editarán en la Revista de Archivos, Bi- } \\
\text { bliotecas y Museos a lo largo de los años siguientes }\end{array}$ \\
\hline 1923 & $\begin{array}{l}\text { Real Orden ordenando la creación de comisiones técnicas que visi- } \\
\text { ten los archivos no servidos por el Cuerpo Facultativo de Archiveros }\end{array}$ \\
\hline 1924 & $\begin{array}{l}\text { Los fondos de la Universidad Central anteriores a } 1901 \text { son transfe- } \\
\text { ridos al Archivo Histórico Nacional }\end{array}$ \\
\hline 1924 & $\begin{array}{l}\text { Se incendia el Archivo de la Academia de Ingenieros del Ejército de } \\
\text { Guadalajara }\end{array}$ \\
\hline 1926 & $\begin{array}{l}\text { Decreto por el que se crea la Junta del Patronato para la Protección } \\
\text { y Acrecentamiento del Tesoro Artístico Nacional }\end{array}$ \\
\hline 1926 & $\begin{array}{l}\text { Proyecto para crear una Asociación de Auxilios Mutuos del Cuerpo } \\
\text { Facultativo de Archiveros }\end{array}$ \\
\hline 1927 & $\begin{array}{l}\text { Real Orden por la que el Estado adquiere el archivo nobiliario de la } \\
\text { Casa de Osuna }\end{array}$ \\
\hline 1927 & $\begin{array}{l}\text { Se crea el Archivo de Protocolos de Lucena del Cid, gracias al } \\
\text { Ayuntamiento de la ciudad, que es el que lo financia }\end{array}$ \\
\hline 1929 & $\begin{array}{l}\text { Real Orden creando un «Taller de Encuadernación de Manuscritos y } \\
\text { Documentos» en el Archivo Histórico Nacional }\end{array}$ \\
\hline 1929 & $\begin{array}{l}\text { Real Orden estableciendo, con una subvención de } 6.000 \text { pesetas al } \\
\text { año, un «servicio de automóviles» entre Valladolid y el Archivo Ge- } \\
\text { neral de Simancas, para uso de funcionarios e investigadores }\end{array}$ \\
\hline 193 & $\begin{array}{l}\text { Real Decreto reformando el Reglamento del Cuerpo de Arcl } \\
\text { Bibliotecarios y Arqueólogos }\end{array}$ \\
\hline
\end{tabular}




\begin{tabular}{|c|c|}
\hline Año & Noticia \\
\hline 1930 & $\begin{array}{l}\text { Miguel Gómez Campillo, Diplomado en la Escuela Superior de Di- } \\
\text { plomática y miembro del Cuerpo de Archiveros, es designado Di- } \\
\text { rector del Archivo Histórico Nacional, puesto que ocupará hasta } \\
1936 \text {, cuando las autoridades republicanas le cesan por haberse su- } \\
\text { mado a la sublevación. En } 1939 \text { será nuevamente nombrado por el } \\
\text { régimen de Franco, ocupando el cargo hasta } 1945\end{array}$ \\
\hline 1930 & $\begin{array}{l}\text { Ángel Plaza Bores, facultativo del Cuerpo de Archiveros, es nom- } \\
\text { brado Director del Archivo General de Simancas }\end{array}$ \\
\hline 1930 & $\begin{array}{l}\text { Real Orden estableciendo que el Director del Archivo Histórico Na- } \\
\text { cional deberá pertenecer inexcusablemente al Cuerpo Facultativo de } \\
\text { Archiveros y Bibliotecarios }\end{array}$ \\
\hline 1931 & $\begin{array}{l}\text { Se crea la red de Archivos Históricos Provinciales, en un primer } \\
\text { momento para custodiar los protocolos notariales con más de } 100 \\
\text { años de antigüedad, luego como centros receptores de la docu- } \\
\text { mentación de la administración periférica del Estado }\end{array}$ \\
\hline 1931 & $\begin{array}{l}\text { Decreto ordenando que los protocolos de más de } 100 \text { años de anti- } \\
\text { güedad sean transferidos a los archivos históricos provinciales }\end{array}$ \\
\hline 1931 & $\begin{array}{l}\text { Don Ramón María del Valle Inclán es nombrado para un puesto de } \\
\text { nueva creación por las autoridades republicanas, el de «Conserva- } \\
\text { dor General del Tesoro Artístico Nacional», con un sueldo de } 8.000 \\
\text { pesetas al año }\end{array}$ \\
\hline 1931 & $\begin{array}{l}\text { Cesa temporalmente de editarse la Revista de Archivos, Bibliotecas } \\
\text { y Museos }\end{array}$ \\
\hline 1931 & $\begin{array}{l}\text { Decreto del Gobierno republicano por el que se crean los «Patrona- } \\
\text { tos Directivos e Inspectores» en el Archivo Histórico Nacional, el Ar- } \\
\text { chivo General de Simancas, el Archivo de la Corona de Aragón, el } \\
\text { Archivo General de Indias «y en cuantos estime el Ministerio» }\end{array}$ \\
\hline 1932 & $\begin{array}{l}\text { Rafael Bori Llovet publica en Barcelona Manual práctico de clasifi- } \\
\text { cación y archivo }\end{array}$ \\
\hline 1932 & $\begin{array}{l}\text { Se crea el «Cuerpo Auxiliar de Archiveros, Bibliotecarios y Arqueó- } \\
\text { logos», luego denominado Cuerpo de Ayudantes }\end{array}$ \\
\hline 1933 & $\begin{array}{l}\text { Ley para la Conservación del Tesoro Artístico Nacional, destinada a } \\
\text { la protección del Patrimonio Histórico español. Su artículo } 4 .^{\circ} \text { se re- } \\
\text { fiere a los fondos de los archivos históricos, estableciendo que una } \\
\text { ley específica los protegerá, pero dicha ley no llegó a dictarse hasta } \\
1972\end{array}$ \\
\hline
\end{tabular}




\begin{tabular}{|c|c|}
\hline Año & Noticia \\
\hline 1933 & $\begin{array}{l}\text { Decreto de creación de la Junta Superior del Tesoro Artístico Na- } \\
\text { cional, dependiente del Ministerio de Instrucción Pública y Bellas Ar- } \\
\text { tes, que sustituye a la Junta de Excavaciones y a la Junta del Pa- } \\
\text { tronato para la Protección y Acrecentamiento del Tesoro Artístico } \\
\text { Nacional }\end{array}$ \\
\hline 1933 & $\begin{array}{l}\text { La Dirección General de Bellas Artes dicta unas Instrucciones pro- } \\
\text { visionales para la clasificación y catalogación de los Archivos Histó- } \\
\text { ricos de Protocolos }\end{array}$ \\
\hline 1933 & $\begin{array}{l}\text { Orden Ministerial por la que se dota de un ascensor al Archivo His- } \\
\text { tórico Nacional }\end{array}$ \\
\hline 1934 & $\begin{array}{l}\text { Decreto por el que se transfieren las competencias sobre los archi- } \\
\text { vos catalanes a la Generalidad de Cataluña }\end{array}$ \\
\hline 1934 & $\begin{array}{l}\text { Decreto de creación de la «Junta Protectora de Bibliotecas y Archi- } \\
\text { vos Eclesiásticos» }\end{array}$ \\
\hline 1934 & $\begin{array}{l}\text { Se vuelve a editar el Anuario del Cuerpo Facultativo de Archiveros, } \\
\text { Bibliotecarios y Arqueólogos, del que sólo se editarán tres números, } \\
\text { hasta } 1935\end{array}$ \\
\hline 1935 & Decreto por el que se crea el Patronato del Archivo General Militar \\
\hline 1936 & $\begin{array}{l}\text { [Bando republicano] El Archivo del Real Patrimonio se ubica en la } \\
\text { sede del ACA }\end{array}$ \\
\hline 1936 & $\begin{array}{l}\text { [Bando republicano] Los registros parroquiales de la Iglesia serán } \\
\text { transferidos a los archivos del Registro Civil }\end{array}$ \\
\hline 1936 & $\begin{array}{l}\text { [Bando franquista] La Gaceta de Madrid pasa a denominarse Boletín } \\
\text { Oficial del Estado }\end{array}$ \\
\hline 1937 & $\begin{array}{l}\text { [Bando republicano] Decreto creando el «Consejo Central de Archi- } \\
\text { vos, Bibliotecas y Tesoro Artístico» }\end{array}$ \\
\hline 1937 & $\begin{array}{l}\text { [Bando republicano] Decreto por el que se crea la Junta Central de } \\
\text { Incautación y Protección del Tesoro Artístico, dependiente del Con- } \\
\text { sejo Central de Archivos, Bibliotecas y Tesoro Artístico, de la que de- } \\
\text { penderán las Juntas Subdelegadas provinciales, y que tratarán de } \\
\text { salvaguardar los bienes del Patrimonio Histórico durante la guerra }\end{array}$ \\
\hline 1937 & $\begin{array}{l}\text { [Bando republicano] El gobierno ordena crear un «Archivo de Gue- } \\
\text { rra» }\end{array}$ \\
\hline 1938 & $\begin{array}{l}\text { [Bando republicano] Agustín Millares Carlo, nombrado Presidente de } \\
\text { la Sección de Archivos del Consejo Central de Archivos, Bibliotecas } \\
\text { y Tesoro Artístico }\end{array}$ \\
\hline
\end{tabular}




\begin{tabular}{c|l} 
Año & Noticia \\
\hline 1938 & $\begin{array}{l}\text { [Bando republicano] Decreto sobre la organización de los «Patro- } \\
\text { natos Provinciales para el Fomento de las Bibliotecas, los Archivos y } \\
\text { los Museos Arqueológicos» }\end{array}$ \\
\hline 1938 & $\begin{array}{l}\text { [Bando franquista] Orden Ministerial ordenando a los funcionarios del } \\
\text { Cuerpo Facultativo de Archiveros y Bibliotecarios que elaboren una } \\
\text { guía sobre los centros que dirigen }\end{array}$ \\
\hline 1939 & $\begin{array}{l}\text { [Bando franquista] Se funda el Archivo Histórico de la Campaña en } \\
\text { Ávila, con fondos sobre la Guerra Civil }\end{array}$ \\
\hline 1939 & $\begin{array}{l}\text { [Bando franquista] Ley creando la Dirección General de Archivos y } \\
\text { Bibliotecas, dependiente del Ministerio de Educación Nacional }\end{array}$ \\
\hline 1939 & $\begin{array}{l}\text { [Bando franquista] Orden Ministerial por la que se crea la «Junta } \\
\text { Técnica de Archivos, Bibliotecas y Museos» }\end{array}$ \\
\hline 1939 & $\begin{array}{l}\text { [Bando franquista] Decreto creando la «Junta Central de Archivos, } \\
\text { Bibliotecas y Museos de España» }\end{array}$ \\
\hline 1942 & $\begin{array}{l}\text { Ley de Presupuestos. La Dirección General de Archivos y Bibliotecas } \\
\text { dispone de un presupuesto de 4,122.989 pesetas. En 1949 serán ya } \\
\text { 12,369.011 pesetas }\end{array}$ \\
\hline $1939-1969$ & $\begin{array}{l}\text { El Archivo Histórico Nacional crea la Sección de «Fondos Contem- } \\
\text { poráneos», con documentación del Tribunal Supremo, la Audiencia } \\
\text { Territorial de Madrid, la Presidencia del Gobierno y los Ministerios de } \\
\text { Hacienda, Obras Públicas e Interior }\end{array}$ \\
\hline 1940 & $\begin{array}{l}\text { Orden Ministerial por la que se crea el Archivo Histórico de Orihuela } \\
\text { dos robados por el ejército napoleónico en Simancas }\end{array}$ \\
\hline 1941 & $\begin{array}{l}\text { Orden Ministerial por la que se crea en el Archivo Histórico Nacional } \\
\text { un «Taller de Restauración», fundación que ya estaba planificada en } \\
\text { 1936 }\end{array}$ \\
\hline $\begin{array}{l}\text { Orden Ministerial dirigida a todos los organismos públicos y particu- } \\
\text { lares para que envíen cualquier documento que posean sobre la ma- } \\
\text { sonería al archivo del Tribunal Especial para la Represión de la } \\
\text { Masonería y del Comunismo de Salamanca }\end{array}$ \\
\hline $\begin{array}{l}\text { Se inician las obras para la nueva sede del Archivo Histórico Nacio- } \\
\text { nal, con un presupuesto de 4,843.604,24 pesetas }\end{array}$ \\
\hline 1942
\end{tabular}




\begin{tabular}{|c|c|}
\hline Año & Noticia \\
\hline 1942 & $\begin{array}{l}\text { Se dota mediante concurso-oposición una plaza de «restaurador-en- } \\
\text { cuadernador» para el Archivo General de Simancas }\end{array}$ \\
\hline 1943 & $\begin{array}{l}\text { Orden Ministerial concediendo ayudas económicas a los archivos ca- } \\
\text { tedralicios y de los monasterios [se reiterarán en años siguientes] }\end{array}$ \\
\hline 1943 & $\begin{array}{l}\text { Orden Ministerial por la que se crea el Archivo Histórico Provincial de } \\
\text { Segovia }\end{array}$ \\
\hline 1943 & $\begin{array}{l}\text { Orden Ministerial por la que se crean el Archivo Histórico Insular de } \\
\text { Mahón y el Histórico Provincial de Teruel }\end{array}$ \\
\hline 1944 & Reglamento para los Archivos Históricos Provinciales de Protocolos \\
\hline 1944 & $\begin{array}{l}\text { Orden Ministerial por la que se crea el Archivo Histórico Provincial de } \\
\text { Badajoz }\end{array}$ \\
\hline 1944 & $\begin{array}{l}\text { Orden Ministerial creando el Archivo Histórico Provincial de Tarra- } \\
\text { gona }\end{array}$ \\
\hline 1945 & $\begin{array}{l}\text { Benito Fuentes Islas, Licenciado en Historia y facultativo del Cuerpo } \\
\text { de Archiveros, es designado Director del Archivo Histórico Nacional, } \\
\text { puesto que ocupará hasta } 1953\end{array}$ \\
\hline 1945 & $\begin{array}{l}\text { Decreto organizando una «Sección Histórica» en los Archivos Pro- } \\
\text { vinciales para conservar los protocolos de más de } 100 \text { años. La } \\
\text { sección estará asesorada por un «Patronato Nacional de Archivos } \\
\text { Históricos de Protocolos». Los documentos serán propiedad del Es- } \\
\text { tado y estarán abiertos a la investigación histórica. Estos protocolos } \\
\text { podrán estar en los Colegios de Notarios siempre que estén bien } \\
\text { conservados y abiertos a la investigación }\end{array}$ \\
\hline 1945 & $\begin{array}{l}\text { Orden Ministerial por la que se crea el Archivo Histórico Provincial de } \\
\text { Granada }\end{array}$ \\
\hline 1945 & $\begin{array}{l}\text { Se habilitan en el Archivo General de Simancas unas habitaciones } \\
\text { para que puedan pernoctar los investigadores }\end{array}$ \\
\hline 1945 & $\begin{array}{l}\text { Orden Ministerial nombrando a Pedro Miguel Gómez del Campillo } \\
\text { Director Honorario del Archivo Histórico Nacional }\end{array}$ \\
\hline 1946 & $\begin{array}{l}\text { Se crea el «Patronato del Archivo Histórico Nacional» (suprimido al } \\
\text { año siguiente) }\end{array}$ \\
\hline 1946 & Orden Ministerial creando el Archivo Histórico Provincial de Córdoba \\
\hline 194 & $\begin{array}{l}\text { Decreto de creación del «Patronato Nacional de Archivos Históri- } \\
\text { cos», en sustitución del «Patronato del Archivo Histórico Nacional» }\end{array}$ \\
\hline
\end{tabular}




\begin{tabular}{|c|c|}
\hline Año & Noticia \\
\hline 1947 & $\begin{array}{l}\text { Decreto sobre la «Ordenación de los archivos y bibliotecas y el te- } \\
\text { soro histórico, documental y bibliográfico». Los archivos quedan } \\
\text { clasificados en seis clases: Generales (Simancas, Indias, Histórico } \\
\text { Nacional y Corona de Aragón); Regionales (Valencia, Galicia); de } \\
\text { Distrito (Chancillerías); Provinciales; de Entidades Públicas y Cor- } \\
\text { poraciones; y de Particulares }\end{array}$ \\
\hline 1947 & Creación del Archivo Central del Ministerio de Fomento \\
\hline 1947 & $\begin{array}{l}\text { Se solicita la creación de una Escuela Técnica de Archivos, Biblio- } \\
\text { tecas y Museos en la Universidad Complutense }\end{array}$ \\
\hline 1947 & $\begin{array}{l}\text { Los fondos del archivo del Hospital Simón Ruiz son transferidos al } \\
\text { Archivo Histórico Provincial de Valladolid }\end{array}$ \\
\hline 1947 & $\begin{array}{l}\text { Decreto ordenando la elaboración del «Catálogo del Tesoro Docu- } \\
\text { mental y Bibliográfico de España» }\end{array}$ \\
\hline 1948 & Se funda el Archivo General de la Marina \\
\hline 1948 & $\begin{array}{l}\text { Se crea el Consejo Internacional de Archivos, dependiente de la } \\
\text { UNESCO }\end{array}$ \\
\hline 1948 & $\begin{array}{l}\text { Se crea el Archivo-Museo de Don Álvaro de Bazán en el Viso del } \\
\text { Marqués (Ciudad Real) }\end{array}$ \\
\hline 1948 & $\begin{array}{l}\text { Orden Ministerial creando los archivos históricos provinciales de } \\
\text { Cuenca, Las Palmas de Gran Canaria y Zaragoza }\end{array}$ \\
\hline 1948 & $\begin{array}{l}\text { Orden Ministerial estableciendo a San Benito como patrono del } \\
\text { Cuerpo Facultativo de Archiveros y Bibliotecarios }\end{array}$ \\
\hline 1949 & $\begin{array}{l}\text { Se funda A.N.A.B.A., la Asociación Nacional de Archiveros, Biblio- } \\
\text { tecarios y Arqueólogos, que en } 1978 \text { cambiará sus siglas por ANA- } \\
\text { BAD y pasará a llamarse Asociación Nacional de Archiveros, Bi- } \\
\text { bliotecarios, Museólogos y Documentalistas }\end{array}$ \\
\hline 1949 & $\begin{array}{l}\text { En la Ley de Presupuestos, la Dirección General de Archivos y Bi- } \\
\text { bliotecas concede una subvención de } 50.000 \text { pesetas a la } \\
\text { A.N.A.B.A. para «congresos y pago de cuotas internacionales» }\end{array}$ \\
\hline 1949 & $\begin{array}{l}\text { La Dirección General de Archivos y Bibliotecas concede a la } \\
\text { A.N.A.B.A. una subvención de } 25.000 \text { pesetas para un «Curso de } \\
\text { Orientación Profesional para Auxiliares de Archivos, Bibliotecas y } \\
\text { Museos» }\end{array}$ \\
\hline 1950 & $\begin{array}{l}\text { Se crea el «Archivo Central del Microfilm», antecedente del Servicio } \\
\text { Nacional de Microfilm }\end{array}$ \\
\hline
\end{tabular}




\begin{tabular}{|c|c|}
\hline Año & Noticia \\
\hline 1950 & Comienza a editarse el Boletín de A.N.A.B.A., luego ANABAD \\
\hline 1950 & Se crea el Archivo Histórico Provincial de Cáceres \\
\hline 1950 & $\begin{array}{l}\text { Orden Ministerial por la que se crea el Archivo Histórico Provincial de } \\
\text { Santander }\end{array}$ \\
\hline 1950 & $\begin{array}{l}\text { Jaime Lladó y Ferragut publica en Palma de Mallorca Guía del ar- } \\
\text { chivero municipal. Normas para clasificar los fondos de un archivo y } \\
\text { formar su índice y catálogo }\end{array}$ \\
\hline 1950 & Se celebra el I Congreso Nacional de Archivos, Bibliotecas y Museos \\
\hline 1951 & $\begin{array}{l}\text { Orden Ministerial por la que se decreta la incorporación del Archivo } \\
\text { Histórico de la Universidad de Salamanca al provincial, que pasará a } \\
\text { llamarse «Archivo Histórico Provincial y Universitario de Vallado- } \\
\text { lid», pero la fusión no llegará a mantenerse }\end{array}$ \\
\hline 1951 & $\begin{array}{l}\text { Comienza a publicarse Archivum, la revista del Consejo Internacional } \\
\text { de Archivos }\end{array}$ \\
\hline 1951 & $\begin{array}{l}\text { Decreto de creación de la Mutualidad del Cuerpo Facultativo de Ar- } \\
\text { chiveros }\end{array}$ \\
\hline 1951 & $\begin{array}{l}\text { Filemón Arribas Arranz publica en la Revista de Archivos, Bibliotecas } \\
\text { y Museos un artículo titulado «Las clasificaciones metódicas y su } \\
\text { aplicación en los archivos» }\end{array}$ \\
\hline 1951 & $\begin{array}{l}\text { Orden Ministerial por la que el Estado adquiere el archivo del Conde } \\
\text { de Torrepando }\end{array}$ \\
\hline 1951 & $\begin{array}{l}\text { Orden Ministerial estableciendo un nuevo Reglamento para el Cuer- } \\
\text { po Facultativo de Archiveros, Bibliotecarios y Arqueólogos }\end{array}$ \\
\hline 1951 & $\begin{array}{l}\text { Real Decreto aumentando el sueldo de los funcionarios del Cuerpo } \\
\text { Facultativo de Archiveros y Bibliotecarios en un } 40 \%\end{array}$ \\
\hline 1952 & $\begin{array}{l}\text { Se construye en Valladolid una «Residencia de Investigadores» } \\
\text { para los usuarios del Archivo General de Simancas }\end{array}$ \\
\hline 1952 & $\begin{array}{l}\text { Inicio de los cursos de formación de archiveros en la Biblioteca Na- } \\
\text { cional, denominados «Cursos de Formación Técnica para futuros ar- } \\
\text { chiveros y bibliotecarios», organizados por la Dirección General de } \\
\text { Archivos y Bibliotecas }\end{array}$ \\
\hline 1952 & $\begin{array}{l}\text { El Archivo Histórico Nacional inaugura su nueva sede madrileña en } \\
\text { el C.S.I.C. }\end{array}$ \\
\hline 1952 & $\begin{array}{l}\text { Se celebra en Madrid el I Congreso Iberoamericano de Archivos, Bi- } \\
\text { bliotecas y Propiedad Intelectual }\end{array}$ \\
\hline
\end{tabular}




\begin{tabular}{|c|c|}
\hline Año & Noticia \\
\hline 1952 & $\begin{array}{l}\text { Se crea el Servicio Nacional de Información Documental y Biblio- } \\
\text { gráfica para formar el "Catálogo del Tesoro Bibliográfico y Docu- } \\
\text { mental de España» }\end{array}$ \\
\hline 1952 & $\begin{array}{l}\text { Orden Ministerial creando los archivos históricos provinciales de } \\
\text { Lérida y de Gerona }\end{array}$ \\
\hline 1952 & $\begin{array}{l}\text { Comienza a editarse el Boletín de la Dirección General de Archivos } \\
\text { y Bibliotecas, que desaparecerá en } 1974\end{array}$ \\
\hline 1952 & $\begin{array}{l}\text { La Dirección General de Archivos y Bibliotecas concede a la } \\
\text { A.N.A.B.A. una subvención de } 47.450 \text { pesetas para la organización } \\
\text { del I Congreso Nacional de Archiveros, Bibliotecarios y Arqueólogos }\end{array}$ \\
\hline 1952 & $\begin{array}{l}\text { José María de la Peña y de la Cámara, nombrado Director del Ar- } \\
\text { chivo General de Indias }\end{array}$ \\
\hline 1953 & Decreto de creación del «Archivo Regional de Galicia» en La Coruña \\
\hline 1953 & $\begin{array}{l}\text { Los fondos del archivo de la Audiencia Territorial de Barcelona son } \\
\text { transferidos al Archivo de la Corona de Aragón }\end{array}$ \\
\hline 1953 & $\begin{array}{l}\text { Decreto reorganizando la «Inspección General de Archivos», cre- } \\
\text { ándose las «Inspecciones Regionales», adaptadas a los Distritos } \\
\text { Universitarios }\end{array}$ \\
\hline 1954 & $\begin{array}{l}\text { Orden Ministerial concediendo } 50.000 \text { pesetas de subvención para la } \\
\text { organización de un «Curso de Archivos» en Jaca }\end{array}$ \\
\hline 1954 & $\begin{array}{l}\text { Luis Sánchez Belda es designado Director del Archivo Histórico Na- } \\
\text { cional, puesto que ocupará hasta } 1984\end{array}$ \\
\hline 1955 & $\begin{array}{l}\text { Orden Ministerial por la que se conceden } 12.000 \text { pesetas de sub- } \\
\text { vención para el «Curso de Formación Técnica de Archiveros y Bi- } \\
\text { bliotecarios» que organiza el Archivo de la Corona de Aragón }\end{array}$ \\
\hline 1955 & $\begin{array}{l}\text { Según recoge el Boletín Oficial del Estado, los sueldos mensuales } \\
\text { brutos de los funcionarios del Cuerpo Facultativo de Archiveros y Bi- } \\
\text { bliotecarios son: } 1 .^{\mathrm{a}} \text { categoría, } 2.300 \text { ptas.; } 2 .^{\text {a }} \text { categoría, } 2.200 \text { ptas.; } \\
3 .^{\text {a }} \text { categoría, } 2.000 \text { ptas.; } 4 .^{\text {a }} \text { categoría, } 1.800 \text { ptas.; } 5 .^{\text {a }} \text { categoría, } \\
1.600 \text { ptas.; } 6 .^{\text {a }} \text { categoría, } 1.400 \text { ptas.; y } 7 .^{\text {a }} \text { categoría, } 1.300 \text { ptas. }\end{array}$ \\
\hline 1956 & $\begin{array}{l}\text { Orden Ministerial por la que se crea la «Sección de Cronistas» en el } \\
\text { Archivo Regional de Valencia }\end{array}$ \\
\hline 1956 & Orden Ministerial creando el Archivo Histórico Provincial de Soria \\
\hline 1957 & $\begin{array}{l}\text { La Junta Técnica de Archivos y Bibliotecas dicta las «Instrucciones } \\
\text { para la catalogación de manuscritos» }\end{array}$ \\
\hline
\end{tabular}




\begin{tabular}{|c|c|}
\hline Año & Noticia \\
\hline 1958 & $\begin{array}{l}\text { El Archivo General de Simancas organiza un «Cursillo Práctico de } \\
\text { Archivos» }\end{array}$ \\
\hline 1958 & $\begin{array}{l}\text { Se dicta la Ley de Procedimiento Administrativo, que por primera vez } \\
\text { regula legislativamente el expediente administrativo en España }\end{array}$ \\
\hline 1958 & $\begin{array}{l}\text { Orden Ministerial por la que se crea el Archivo Histórico Provincial de } \\
\text { Teruel }\end{array}$ \\
\hline 1959 & $\begin{array}{l}\text { Orden Ministerial por la que se crea el Archivo General del Ministerio } \\
\text { de Obras Públicas }\end{array}$ \\
\hline 1960 & $\begin{array}{l}\text { Antonio Matilla Tascón publica en Madrid su Cartilla de organización } \\
\text { de archivos }\end{array}$ \\
\hline 1960 & $\begin{array}{l}\text { Agustín Gómez Iglesias publica en el Boletín de la A.N.A.B.A. un ar- } \\
\text { tículo titulado: “Organización, instalación, conservación y gobierno } \\
\text { de los archivos de los ayuntamientos y las Diputaciones» }\end{array}$ \\
\hline 1960 & $\begin{array}{l}\text { La Dirección General de Archivos y Bibliotecas dicta las «Normas } \\
\text { sobre el servicio público de archivos, bibliotecas y museos y régimen } \\
\text { de la propiedad intelectual» }\end{array}$ \\
\hline 1961 & $\begin{array}{l}\text { Se pone en marcha en el Archivo General de Simancas el «Curso } \\
\text { de Archivística Hispanoamericana», que se repetirá los dos años si- } \\
\text { guientes }\end{array}$ \\
\hline 1961 & $\begin{array}{l}\text { Decreto declarando Monumento Histórico-Artístico al Archivo del } \\
\text { Adelantamiento de Castilla en Covarrubias (Burgos) }\end{array}$ \\
\hline 1961 & $\begin{array}{l}\text { Se crea el Instituto Central de Conservación y Restauración de } \\
\text { Obras y Objetos de Arte, Arqueología y Etnología (I.C.C.R.), del } \\
\text { que surgirá en } 1969 \text { el Servicio Nacional de Restauración de Libros } \\
\text { y Documentos }\end{array}$ \\
\hline 1961 & $\begin{array}{l}\text { La Asamblea de la A.N.A.B.A. solicita al Ministerio un aumento de } \\
\text { sueldo para los funcionarios del Cuerpo de Archiveros }\end{array}$ \\
\hline 1961 & $\begin{array}{l}\text { Jesús Ernesto Martínez Ferrando, que había sido Director del Ar- } \\
\text { chivo de la Corona de Aragón desde 1916, es nombrado «Director } \\
\text { Honorario» }\end{array}$ \\
\hline 1961 & $\begin{array}{l}\text { Federico Udina Martorell, nombrado Director del Archivo de la Co- } \\
\text { rona de Aragón }\end{array}$ \\
\hline 1962 & $\begin{array}{l}\text { Se crea la Sección «Documentación Moderna» en el Archivo Histó- } \\
\text { rico Nacional }\end{array}$ \\
\hline
\end{tabular}




\begin{tabular}{|c|c|}
\hline Año & Noticia \\
\hline 1962 & $\begin{array}{l}\text { Reglamento de los archivos dependientes del Ministerio de Educa- } \\
\text { ción Nacional }\end{array}$ \\
\hline 1962 & $\begin{array}{l}\text { Orden Ministerial creando los archivos históricos provinciales de } \\
\text { León y Albacete }\end{array}$ \\
\hline 1963 & Se celebra en Sevilla el I Congreso Nacional de Archivos \\
\hline 1963 & $\begin{array}{l}\text { Luis Sánchez Belda, Director General de Archivos y Bibliotecas, } \\
\text { publica en Madrid Bibliografía de archivos españoles y archivística }\end{array}$ \\
\hline 1963 & Se celebra en Sevilla el I Congreso Nacional de Archivos \\
\hline 1964 & $\begin{array}{l}\text { Inicia su andadura la «Escuela de Documentalistas» en la Biblioteca } \\
\text { Nacional, organizada por la Dirección General de Archivos y Biblio- } \\
\text { tecas }\end{array}$ \\
\hline 1964 & $\begin{array}{l}\text { Emilio del Río Pérez publica en Madrid Manual práctico del archivo } \\
\text { militar }\end{array}$ \\
\hline 1964 & $\begin{array}{l}\text { Ángel de la Plaza Bores publica en Madrid: “Archivo General de Si- } \\
\text { mancas. Guía del investigador» }\end{array}$ \\
\hline 1965 & El Archivo del Reino de Valencia estrena nuevo edificio \\
\hline 1965 & $\begin{array}{l}\text { Rosario Parra Cala, nombrada Directora del Archivo General de In- } \\
\text { dias }\end{array}$ \\
\hline 1967 & Se funda el Archivo General Militar de Guadalajara \\
\hline 1967 & $\begin{array}{l}\text { Creación en el I.C.C.R. del Departamento de «Grabados, Dibujos, } \\
\text { Libros y Manuscritos», antecesor del Servicio Nacional de Restau- } \\
\text { ración }\end{array}$ \\
\hline 1968 & $\begin{array}{l}\text { Decreto reorganizando la Junta Facultativa de Archivos, Bibliote- } \\
\text { cas y Museos }\end{array}$ \\
\hline 1968 & Se celebra en Madrid el VI Congreso Internacional de Archivos \\
\hline 1969 & $\begin{array}{l}\text { Decreto de creación del Archivo General de la Administración Civil } \\
\text { en Alcalá de Henares, que sustituiría al quemado durante la guerra }\end{array}$ \\
\hline 1969 & $\begin{array}{l}\text { Decreto de creación del Servicio Nacional de Restauración de Libros } \\
\text { y Documentos }\end{array}$ \\
\hline 1969 & Orden Ministerial por el que se crea el Archivo Histórico de Melilla \\
\hline 1969 & Francisco Lliset Borrell publica en Madrid El archivo municipal \\
\hline 1969 & $\begin{array}{l}\text { La Conferencia Episcopal crea la «Junta Nacional del Tesoro Do- } \\
\text { cumental y Bibliográfico de la Iglesia Española» }\end{array}$ \\
\hline
\end{tabular}




\begin{tabular}{|c|c|}
\hline Año & Noticia \\
\hline 1969 & $\begin{array}{l}\text { La Dirección General de Archivos y Bibliotecas dicta unas nuevas } \\
\text { «Instrucciones para la catalogación de manuscritos» }\end{array}$ \\
\hline 1969 & $\begin{array}{l}\text { Orden Ministerial por la que se crea en Madrid la «Escuela de Artes } \\
\text { Aplicadas a la Restauración» }\end{array}$ \\
\hline 1970 & Se celebra en Pamplona el III Congreso Nacional de Archivos \\
\hline 1971 & $\begin{array}{l}\text { Orden Ministerial estableciendo la gratuidad del acceso a los archi- } \\
\text { vos y bibliotecas del Estado }\end{array}$ \\
\hline 1971 & Se funda la «Asociación de Archiveros de la Iglesia Española» \\
\hline 1971 & $\begin{array}{l}\text { María del Carmen Pescador del Hoyo publica en el Boletín de la } \\
\text { A.N.A.B.A. un artículo titulado «La cibernética aplicada a la explota- } \\
\text { ción de fondos de archivos» }\end{array}$ \\
\hline 1971 & $\begin{array}{l}\text { Se celebra en Madrid el I Congreso Nacional de Archiveros Ecle- } \\
\text { siásticos }\end{array}$ \\
\hline 1972 & $\begin{array}{l}\text { Ley para la defensa del Tesoro Documental y Bibliográfico de la } \\
\text { Nación }\end{array}$ \\
\hline 1972 & Decreto de creación del Archivo General e Histórico del Aire \\
\hline 1972 & Decreto por el que se funda el Servicio Nacional de Microfilm \\
\hline 1972 & $\begin{array}{l}\text { El Archivo General de la Administración recibe sus primeras trans- } \\
\text { ferencias de documentos }\end{array}$ \\
\hline 1972 & $\begin{array}{l}\text { La O.E.A. (Organización de Estados Americanos) y la Dirección } \\
\text { General de Archivos y Bibliotecas inician los cursos iberoamericanos } \\
\text { sobre «Organización y administración de archivos» }\end{array}$ \\
\hline 1972 & $\begin{array}{l}\text { El Ministerio de Educación y Ciencia publica el Censo-Guía de los } \\
\text { archivos españoles }\end{array}$ \\
\hline 1972 & Se celebra en Barcelona el IV Congreso Nacional de Archivos \\
\hline 1973 & $\begin{array}{l}\text { Inauguración de la nueva sede del Archivo de la Chancillería de } \\
\text { Valladolid }\end{array}$ \\
\hline 1973 & Se reorganiza la Inspección General de Archivos y Bibliotecas \\
\hline 1973 & $\begin{array}{l}\text { Fundación en el Servicio Nacional de Restauración de la «Escuela } \\
\text { de Formación de Técnicos Restauradores de Documentos Gráfi- } \\
\text { cos», que funcionará hasta } 1979\end{array}$ \\
\hline 1973 & $\begin{array}{l}\text { Orden Ministerial por la que se crea la Sección de Biblioteca y Ar- } \\
\text { chivo del Ministerio de la Vivienda }\end{array}$ \\
\hline
\end{tabular}




\begin{tabular}{|c|c|}
\hline Año & Noticia \\
\hline 1974 & $\begin{array}{l}\text { Dos Órdenes Ministeriales crean los archivos históricos provinciales } \\
\text { de Huelva y Alicante }\end{array}$ \\
\hline 1974 & $\begin{array}{l}\text { Orden Ministerial por la que el Archivo General de la Administración } \\
\text { se incorpora al Archivo Histórico Nacional, asumiendo el Director de } \\
\text { éste la dirección de ambos centros }\end{array}$ \\
\hline 1974 & $\begin{array}{l}\text { Decreto de creación de la Dirección General del Patrimonio Artístico } \\
\text { y Cultural (suprimida en 1980) }\end{array}$ \\
\hline 1975 & $\begin{array}{l}\text { Orden Ministerial por el que se crea el Archivo Histórico Provincial de } \\
\text { Burgos }\end{array}$ \\
\hline 1975 & Orden creando el Archivo Histórico Provincial de Cádiz \\
\hline 1975 & $\begin{array}{l}\text { Se celebra en Toledo el // Congreso Nacional de Archiveros Ecle- } \\
\text { siásticos }\end{array}$ \\
\hline 1976 & $\begin{array}{l}\text { Orden Ministerial por el que se crea el Archivo Histórico Provincial de } \\
\text { Murcia }\end{array}$ \\
\hline 1976 & $\begin{array}{l}\text { Inauguración oficial del Archivo General de la Administración de Al- } \\
\text { calá de Henares }\end{array}$ \\
\hline 1976 & $\begin{array}{l}\text { La Conferencia Episcopal dicta el «Reglamento de los Archivos y Bi- } \\
\text { bliotecas de la Iglesia Española» }\end{array}$ \\
\hline 1976 & $\begin{array}{l}\text { María del Carmen Pescador del Hoyo publica en el Boletín de la } \\
\text { A.N.A.B.A. un artículo titulado: «Aplicación de la informática en los } \\
\text { fondos de los archivos españoles» }\end{array}$ \\
\hline 1976 & $\begin{array}{l}\text { María Auxiliadora Carmona de los Santos publica en el Boletín de la } \\
\text { A.N.A.B.A. un artículo titulado «Ensayo de mecanización de índices } \\
\text { en el Archivo Histórico Provincial de Cádiz» }\end{array}$ \\
\hline 1977 & $\begin{array}{l}\text { Orden Ministerial por la que se crean los Archivos Históricos Pro- } \\
\text { vinciales de Valladolid, Mahón, Almería, Ávila, Ciudad Real, Guada- } \\
\text { lajara, Huesca, Jaén, Málaga, Orense, Palencia, Pontevedra, Sala- } \\
\text { manca, Santa Cruz de Tenerife, Toledo y Zamora }\end{array}$ \\
\hline 1977 & $\begin{array}{l}\text { Creación del «Centro de Información Documental de Archivos» } \\
\text { (C.I.D.A.) }\end{array}$ \\
\hline 1977 & $\begin{array}{l}\text { Los archivos históricos pasan a depender orgánicamente del Mi- } \\
\text { nisterio de Cultura }\end{array}$ \\
\hline
\end{tabular}

